\title{
Lovgivers rolle som fortolker af internationale retskilder
}

På hvilken måde gælder menneskerettighederne i Danmark?

Koch, Pernille Boye

Published in:

Tidsskrift for Rettsvitenskap

DOI:

10.18261/issn.1504-3096-2019-01-01

Publication date:

2019

Document Version

Peer-review version

Citation for published version (APA):

Koch, P. B. (2019). Lovgivers rolle som fortolker af internationale retskilder: På hvilken måde gælder menneskerettighederne i Danmark? Tidsskrift for Rettsvitenskap, 132(1), 3-50.

https://doi.org/10.18261/issn.1504-3096-2019-01-01

\section{General rights}

Copyright and moral rights for the publications made accessible in the public portal are retained by the authors and/or other copyright owners and it is a condition of accessing publications that users recognise and abide by the legal requirements associated with these rights.

- Users may download and print one copy of any publication from the public portal for the purpose of private study or research.

- You may not further distribute the material or use it for any profit-making activity or commercial gain.

- You may freely distribute the URL identifying the publication in the public portal.

Take down policy

If you believe that this document breaches copyright please contact rucforsk@kb.dk providing details, and we will remove access to the work immediately and investigate your claim. 


\section{Lovgivers rolle som fortolker af internationale retskilder - på hvilken måde gælder menneskerettighederne i Danmark?}

Pernille Boye Koch, cand. jur., ph.d., lektor i offentlig ret, Roskilde Universitet,

\section{Indledning}

Forholdet mellem national og international ret er et tema, der til stadighed diskuteres i Danmark. I modsætning til mange andre lande har vi ikke i forfatningen en bestemmelse, der mere udtrykkeligt forholder sig til internationale retskilders betydning, og vi har kun i meget begrænset omfang foretaget en egentlig inkorporering af menneskerettighedskonventioner. Danmark har fortsat kun inkorporeret Den Europæiske Menneskerettighedskonvention (1992) og ikke fx centrale FN-konventioner, selv om spørgsmålet har været rejst flere gange. Det har imidlertid været et gennemgående argument i de juridiske og politiske debatter om inkorporering af yderligere konventioner, at den eksisterende magtfordeling mellem lovgivningsmagten og domstolene bør fastholdes, således at domstolene ikke skal tildeles en større retspolitisk opgave som selvstændig fortolker af internationale normer, end den traditionelle forfatningskultur tilsiger. I forlængelse heraf understreges ofte, at det er lovgivningsmagten, som har det primære ansvar for at sikre en løbende efterlevelse af de konventionsmæssige forpligtelser.

Dette rejser naturligt spørgsmålet, hvordan lovgivningsmagten i Danmark så har praktiseret dette udbredte ansvar for at implementere internationale retsnormer i den nationale ret. Derom er der desværre ikke lavet større grundlæggende undersøgelser ${ }^{1}$. Denne artikel vil i et vist omfang råde bod herpå, idet den vil analysere centrale nyere lovforslag, hvor de nye regler rejser spørgsmål om internationale menneskerettigheder, og hvor regeringen ved fremsættelsen af lovforslagene i st $\varnothing$ rre eller mindre omfang redegør for forholdet til konventionsmæssige forpligtelser. Analysen vil udlede en række fælles karakteristika ved lovgivningsmagtens håndtering af ansvaret for overholdelsen af internationale forpligtelser og i forlængelse heraf efterprøve den forfatningsretlige præmis om ansvarsfordeling mellem lovgivningsmagt, administrative myndigheder og domstole. Endelig vil artiklen i den diskuterende del reflektere over, i hvilket omfang resultaterne rykker ved gængse opfattelser og fortolkningsprincipper, når man skal vurdere menneskerettighedernes gennemslagskraft i Danmark.

\section{Internationale menneskerettigheder i dansk ret - oversigt og kontekst}

For at forstå regeringen og Folketingets håndtering af de internationale retsnormer i det lovforberedende arbejde, er det indledningsvist nødvendigt at få et overblik over den danske forfatningsretlige kontekst og gøre sig klart, hvad den juridiske status af internationale menneskerettigheder er i Danmark. I det følgende introduceres derfor til en række grundlæggende karakteristika ved den danske forfatningsretlige ordning, og der gives en opsummering af positionerne i dansk juridisk teori, de gængse anerkendte fortolkningsprincipper og diskussionerne om betydningen af inkorporering.

\footnotetext{
${ }^{1}$ På EU-rettens område er der derimod foretaget unders $\emptyset$ gelser, se Dorte Sindbjerg Martinsen: Danmarks implementering af EU-politik, Politica 45. årgang nr. 4, 2013, s. 437-456.
} 


\subsection{Menneskerettigheder - spinkel national forankring}

I modsætning til de fleste andre nordiske lande har Danmark ikke et opdateret rettighedskatalog i den nationale forfatning. Den danske grundlov er ikke blevet grundlæggende ændret siden 1953, og mange af forfatningens bestemmelser stammer helt tilbage fra den allerførste grundlov af $1849^{2}$. Grundlovens rettighedskatalog har som følge heraf et noget arkaisk præg i såvel sprogbrug som indhold. Det omfatter primært de klassiske frihedsrettigheder, og bestemmelserne er for fleres vedkommende blevet fortolket indskrænkende af de danske domstole, der typisk har anlagt en tilbageholdende grundlovsfortolkning ${ }^{3}$. Dette indebærer, at mange af de internationale menneskerettighedskonventioner, som Danmark i lighed med de fleste andre demokratiske lande har ratificeret, ofte indeholder en noget mere vidtgående regulering af og beskyttelse af menneskerettighederne ${ }^{4}$, end den nationale forfatning gør.

Den ikke-opdaterede grundlov betyder imidlertid også, at man ikke i forfatningen udtrykkeligt har forholdt sig til, hvilken status internationale konventioner skal have i det nationale retssystem ${ }^{5}$. Og det er faktisk ikke kun på forfatningsniveau, der er tavst. Der findes heller ikke på lovniveau en regulering af menneskerettigheder, der forholder sig til spørgsmålet om inkorporering, indplacering i retskildehierarkiet, eller som differentierer mellem forskellige konkrete konventioner.

Danmark har siden 1972 været medlem af Den Europæiske Union, og EU-retten har i modsætning til folkeretten en relativt fasttømret status i det nationale system, idet den som udgangspunkt betragtes som havende direkte virkning og forrang for dansk ret, medmindre den er i strid med regler på grundlovsniveau ${ }^{6}$. EU-traktaterne har bl.a. denne status som supranational ret i kraft af, at de er vedtaget i overensstemmelse med reglerne om suverænitetsafgivelse i grundlovens $\S 20^{7}$.

Et andet vigtigt karakteristikum for det danske forfatningssystems håndtering af internationale retsnormer er, at der ikke eksisterer egentlige systemer for uafhængig kontrol med lovgivningens overensstemmelse med grundlæggende rettigheder ${ }^{8}$. For det første har Danmark ikke en egentlig forfatningsdomstol, men herved adskiller Danmark sig jo ikke fra de resterende nordiske lande. Mere bemærkelsesværdigt er det velsagtens, at man heller ikke har etableret andre kontrolformer, der kan sikre en form for forudgående regeringsuafhængig kontrol med fremlagte lovforslags forhold til menneskerettighederne. Der eksisterer således ikke systemer eller procedurer, der fx kan sammenlignes ${ }^{9}$ med den, der foregår i Sverige ved Lagrådet ${ }^{10}$, eller som det finske system med kontrol ved' Perustuslakivaliokunta' (Grundlagsutskottet) ${ }^{11}$.

\footnotetext{
${ }^{2}$ Se fx Jens Elo Rytter: Individets grundlæggende rettigheder, 2. udgave, 2016, s. $21 \mathrm{ff}$

3 Jf. fx Henrik Zahle: Dansk forfatningsret 3, 3. udgave, 2010, s. 53 og Jens Peter Christensen m.fl. (red): Grundloven med kommentarer, 2015, s. 93 f.

4 Jf. Jens Elo Rytter: Grundrettigheder, 2000, s. xx

5 Jf. Henrik Zahle: Dansk forfatningsret 2, 3. udgave, 2003, s. $213 \mathrm{f}$.

${ }^{6}$ Jf. UfR $1998.800 \mathrm{H}$

7 Jf. fx Peter Blume: Juridisk Metodelære, 2009, s. 214.

${ }^{8}$ Se Pernille Boye Koch: Forfatningskontrol i Henrik Zahle (red.): Danmarks Riges Grundlov med kommentarer, 2006, s. $53 \mathrm{ff}$.

${ }^{9}$ Jf. Pernille Boye Koch: Forfatningskontrol - fremtidige perspektiver og udfordringer, 2002.

${ }^{10}$ Se fx Anders Eka: Lagrådet och rättstillämpningen, Svensk Juristtidning 2009, vol. 3, s. $261 \mathrm{ff}$ og

${ }^{11}$ Se fx Juha Lavapuro, Tuomas Ojanen and Martin Scheinin: Rights-Based Constitutionalism in Finland and the Development of Pluralist Constitutional Review', (2011) 9 Intl J Cons L 505.
} 
Dette indebærer, at Folketinget og offentligheden i vidt omfang er overladt til at stole på de vurderinger af fremlagte lovforslags forhold til menneskerettighederne, som regeringens og centraladministrationens embedsmænd fremkommer med i lovforslagets bemærkninger. Der er ikke i det danske parlament hverken tradition for eller ressourcer til lade Folketingets egne embedsmænd udarbejde partineutrale vurderinger om supplement til regeringens ${ }^{12}$.

Alt i alt betyder disse forfatningsmæssige forhold, at den eneste systematiske eksterne kontrol med regeringens umiddelbare vurdering af lovens forhold til og overensstemmelse med menneskerettighederne, finder sted ved en eventuel efterfølgende prøvelse ved de almindelige domstole. Denne potentielle domstolskontrol er imidlertid også i et vist omfang begrænset, idet lovgivningsmagten har pålagt de danske domstole at være tilbageholdende i fortolkningen af internationale menneskerettighedskonventioner, hvilket skal uddybes nedenfor.

Den sporadiske eksplicitte stillingtagen til international rets status i grundloven eller lovgivningen i $\varnothing v r i g t, ~ g \emptyset r$ det naturligvis mere naturligt at rette blikket mod retslitteraturen og retspraksis.

\subsection{Litteraturen om forholdet mellem national og international ret}

Litteraturens behandling af betydningen af folkeret i dansk ret har i ganske vidt omfang været en kombination af en række mere retsteoretiske, logiske og normative betragtninger med en ofte mere sporadisk behandling af de internationale normers faktiske gennemslag i praksis. Alf Ross og hans lærebog i folkeret fra $1942^{13}$ må betragtes som central og har præget diskussionerne helt frem til nu, men også Ole Espersens disputats fra 1970 om traktater ${ }^{14}$ og Henrik Zahles synspunkter om praktisk monisme ${ }^{15}$ er vigtig for en forståelse af diskussionerne i dansk juridisk teori.

I den helt tidlige teori fra 1800 -tallet og første halvdel af 1900 -tallet ${ }^{16}$ var synspunkterne inspireret af mere retsteoretiske og retsfilosofiske ræsonnementer. Dette var formentlig en konsekvens af, at folkeretten som disciplin udspringer fra naturretsfilosofien, og at spørgsmålet kan kvalificeres som en grundlæggende retskildediskussion, men det hænger nok også sammen med, at der simpelthen ikke eksisterede relevant retseller lovgivningspraksis, som man kunne læne sig op ad. Ross skriver så sent som i 1961 for eksempel følgende:

\footnotetext{
"Jeg har ikke bemærket nogen dansk dom der udtrykkeligt er kommet ind på problemet om forholdet mellem dansk ret og folkeret, og kun nogle få stykker der forudsætningsvist berører dette problem, antagelig dog uden at domstolen har været sig dettes indhold klart bevidst" ${ }^{17}$
}

\footnotetext{
${ }^{12}$ Se fx Pernille Boye Koch: Myten om det stærke folketing og ansatser til et realitetstjek, Tidskriftet Futuriblerne 2015, s. 33-38.

${ }^{13}$ Alf Ross: Lærebog i Folkeret, Almindelig Del, 1. udgave. Munksgaard 1942.

${ }^{14}$ Ole Espersen: Indgåelse og opfyldelse af traktater. Juristforbundet, 1970.

${ }^{15}$ Henrik Zahle: Dansk forfatningsret 2 - Regering, forvaltning og dom, 3. udgave 2001, kapitel 50 og 51.

${ }^{16}$ For eksempel Henning Matzen: Den danske Statsforfatningsret, del l, 1. udgave, 1888 og Knud Berlin: Den danske Statsforfatningsret, del l, 1. udgave, 1916. For en mere udførlig oversigt over teorien, se Ole Terkelsen: Folkeret og dansk ret. Karnov Group, 2017, s. $21 \mathrm{ff}$.

${ }^{17}$ Alf Ross: Lærebog i Folkeret, Almindelig Del, 4. udgave. Nyt Nordisk Forlag Arnold Busck, 1961.
} 
Når dansk ret således traditionelt siges at være baseret på det dualistiske princip, hvorefter dansk ret og international ret er to adskilte retssystemer, således at folkeretten ikke kan anvendes direkte, er det altså $\mathrm{i}$ ganske vidt omfang et udtryk for, at de tidlige teoretikere på området - Henning Matzen, Knud Berlin, Poul Andersen og Alf Ross - på baggrund af logiske og retsfilosofiske ræsonnementer fandt denne model mest overbevisende. Der lå efter forfatternes opfattelse en stringens $i$, at folkeretten (kun) gælder for staterne, altså mellem de parter der har indgået den pågældende traktat, mens den nationale ret gælder $i$ staterne ${ }^{18}$.

Også grundlovens § 19 om regeringens indgåelse af traktater og Folketingets kontrol hermed er dog blevet inddraget i diskussionerne, idet særligt formuleringen om samtykke ved indgåelse af forpligtelser "til hvis opfyldelse Folketingets medvirken er nødvendig", fremhæves. Argumentet lyder, at ordlyden forudsætter opfyldelsesforanstaltninger fra Folketingets side og dermed et dualistisk system. Som det dog er blevet fremhævet af flere ${ }^{19}$, giver hverken bestemmelsens ordlyd, formål eller forarbejder imidlertid noget klart svar på, i hvilke situationer sådanne opfyldelsesforanstaltninger er nødvendige, og det er da også en udbredt opfattelse i litteraturen, at grundlovsbestemmelsen primært havde til hensigt at regulere forholdene udadtil og ikke regulere retstilstanden indadtil. Det er således vanskeligt at udlede klare svar om forholdet mellem dansk ret og international ret af den eksisterende grundlov.

Tilslutningen til det dualistiske princip har ikke været fuldstændig i den juridiske teori. Særligt Ole Espersen har været set som eksponent for en monistisk tilgang idet han i sin disputats fra 1970 hævdede, at "traktater uden videre en del af gældende dansk ret" ${ }^{20}$, men også Henrik Zahle skiller sig lidt ud fra traditionen med sin introduktion af begrebet "praktisk monisme". Der synes dog at være en væsentlig forskel på disse to teoretikere, idet Espersens synspunkter primært er en teoretisk funderet kritik af Alf Ross' logiske retskildeopfattelse (og således i vidt omfang en fortsættelse af tendensen til retsfilosofisk orienterede analyser), mens Zahles synspunkter er et mere praktisk funderet fors $\varnothing \mathrm{g}$ på at beskrive gældende ret, som den kommer til udtryk i retsanvendelsen. Zahle anfører da også som et grundsynspunkt følgende:

"For spørgsmålet om, hvorledes international ret kan og eventuelt skal anvendes som led i den natio-
nale ret, er modsætningen mellem monistiske og dualistiske teorier i den hidtidige litteratur betragtet
som central. Jeg tror, at det vil tjene til en afklaring af problemstillingen, om man uden videre erkender,
at diskussionen mellem monister og dualister ikke har nogen som helst relevans for drøftelsen af, hvor-
vidt og på hvilke vilkår international ret kan anvendes ved nationale myndigheder. Det er et fejlgreb at
sammenkoble disse generelle retsteoretiske anskuelser med det praktiske spørgsmål om anvendelse af
international ret ved nationale myndigheder." 21

Zahles behandling af spørgsmålet kan altså ses som et udtryk for en ny, mere pragmatisk og praktisk orienteret tilgang til spørgsmålet om international ret i dansk ret. $^{22}$

\footnotetext{
${ }^{18}$ Matzen, op.cit., s. 28ff, Berlin, op.cit., s. 73 og Poul Andersen: Statsforfatningsret, del l, 1944, s. 138. Se også Terkelsen, op. cit. s. $30 f$.

${ }^{19}$ Se bl.a. Mohammed Ahsan og Søren Skibsted: Menneskerettighedskonventioners retskildemæssige status i dansk ret, Juristen nr. 3, 2002, s. $92 \mathrm{ff}$.

20 Jf. Ole Espersen s. 163.

${ }^{21}$ Zahle op.cit. s. 212.

${ }^{22}$ Samtidigt kan Zahles synspunkter imidlertid også anskues som et led i den retsteoretiske bølge i nordisk juridisk teori, der i slutningen af 1980'erne og begyndelsen af 1990'erne blev introduceret under betegnelsen "retlig polycentri", og
} 
Zahles praktiske monisme kan sammenfattes som et synspunkt om, at international ret er relevant ved bedømmelsen af nationale retsspørgsmål og potentielt set kan afgøre udfaldet af sagen, men at eventuelle konflikter mellem internationalt og nationalt retskildemateriale ikke lader sig løse efter enkle principper ${ }^{23}$. Synspunktet om praktisk monisme har dog ikke som sådan vundet tilslutning blandt andre teoretikere, hvorfor retstilstanden fortsat beskrives som værende udtryk for dualisme ${ }^{24}$. Imidlertid synes Zahles synspunkter at have indvarslet en tendens i litteraturen til at foretage en mere praksisnær analyse af folkerettens status i dansk ret.

\subsection{Fortolknings-, formodnings- og instruktionsreglen}

Et fælles karakteristikum for stort set alle fremstillinger af international ret i dansk ret er, at de inkluderer fortolknings-, formodnings- og instruktionsreglen i deres beskrivelse af gældende ret. De to førstnævnte og mest klassiske principper, fortolknings- og formodningsreglen, blev introduceret af Alf Ross i mere systematisk form i 1942 og senere videreført af stort set alle de folkeretlige og forfatningsretlige forfattere, inkl. Ole Espersen. I den seneste inkorporeringsbetænkning fra $2014^{25}$ er fortolkningsreglen formuleret på følgende vis:

"Fortolkningsreglen indebærer efter den almindelige opfattelse, at danske retsregler ved fortolkningstvivl skal søges fortolket på en måde, der bringer dem i overensstemmelse med Danmarks internationale forpligtelser"

Også formodningsreglen er et harmoniseringsprincip, der dog har en lidt anden karakter, idet den fastslår, at

"danske domstole og andre retsanvendende myndigheder skal tage udgangspunkt i, at lovgiver må formodes ikke at ville handle i strid med Danmarks folkeretlige forpligtelser (...) og derfor så vidt muligt søge at anvende de nationale regler på en sådan måde, at en krænkelse af de internationale forpligtelser undgås" 26

Her tager man altså udgangspunkt i situationer, hvor man ikke umiddelbart kan fortolke sig ud af en potentiel konflikt med den internationale ret, fordi ordlyden af den nationale bestemmelse kun vanskeligt giver anledning til tvivl, men hvor man ikke desto mindre i den konkrete subsumption anvender reglen på en konventionskonform måde ud fra en forudsætning om, at dette må være lovgivers $ø$ nske.

En sidste, nyere tilkommen, regel for inddragelse af internationale retskilder, er den såkaldte instruktionsregel, som retter sig mod forvaltningen:

hvor Zahle sammen med danske og nordiske kollegaer plæderede for et mere pluralistisk retskildebegreb. Den polycentriske tankegang forsøgte at gøre op med forestillingen om ét retssystem baseret på traditionelle hierarkiske logikker og med ét fælles værdigrundlag; se særligt Peter Blume og Hanne Petersen (red.): Retlig polycentri, Akademisk Forlag, 1993. I stedet understregede man, at retten skabes i mange forskellige parallelle centre, og at der næppe kan opstilles faste regler om retskildernes indbyrdes hierarki ved afgørelsen af konkrete retsspørgsmål.

${ }^{23}$ Han udvikler herefter en række analytiske delregler baseret på retspraksis, der skal fungere som alternative hjælperedskaber i beskrivelsen af international ret i dansk ret, jf. i det hele Zahle, op.cit. s. 219.

${ }^{24}$ Se fx Jens Peter Christensen m.fl. (red.): Grundloven med kommentarer, Jurist- og Økonomforbundets Forlag, 2015,

s. 155-156 og Jens Elo Rytter: Individets grundlæggende rettigheder, 2016, s. 59.

${ }^{25}$ Betænkning nr. 1546 om inkorporering mv. inden for menneskeretsområdet, Justitsministeriet 2014.

${ }^{26}$ Betænkning nr. 1546/2014, s. 35 
Ifølge instruktionsreglen "skal administrative myndigheder udnytte skønsmæssige beføjelser på en måde, så international ret respekteres og brud undgås." 27

Disse tre fortolkningsmæssige regler eller principper er efterhånden blevet doceret i årtier og udgør det mere konkrete grundlag for, at international ret betragtes som værende en del af dansk ret. Dette ændrer dog ikke ved, at de tre "regler" i deres formulering opretholder en klar forestilling om, at konventionerne er noget accessorisk til de nationale regler, der opfattes som det primære eller egentlige. De internationale forpligtelser er fortolkningsbidrag eller udfyldende materiale og dermed noget subsidiært. Desuden har reglerne karakter af harmoniseringsprincipper og forholder sig derfor ikke til, når sagen sættes på spidsen, altså hvordan man bedømmer regulære normkonflikter mellem national og international ret. ${ }^{28}$

\subsection{Inkorporering - nølende og ambivalent}

Det er et bemærkelsesværdigt kendetegn ved den danske opfattelse af internationale retskilder, at der er et meget tvetydigt syn på betydningen af inkorporering. Det er således ganske svært at blive klog på, hvilken retlig betydning danske myndigheder tillægger inkorporering af internationale konventioner til trods for, at spørgsmålet er blevet behandlet af adskillige sagkyndige betænkninger ${ }^{29} \mathrm{i}$ årenes $\mid \varnothing \mathrm{b}$. Amivalensen har blandt andet givet sig udslag i, at Danmark kun har valgt at inkorporere i Den Europæiske Menneskerettighedskonvention, selv om yderligere inkorporering har været behandlet og anbefalet i flere omgange af sagkyndige kommissioner. I det følgende gives et overblik over de mest centrale internationale menneskerettighedskonventioner:

\begin{tabular}{|l|l|l|l|l|c|}
\hline & $\begin{array}{l}\text { Danmarks } \\
\text { ratifikation }\end{array}$ & $\begin{array}{l}\text { Anbefales } \\
\text { inkorporeret } \\
\mathrm{i} \text { 1991? }\end{array}$ & $\begin{array}{l}\text { Anbefales } \\
\text { inkorporeret } \\
\mathrm{i} \text { 2001? }\end{array}$ & $\begin{array}{l}\text { Anbefales } \\
\text { inkorporeret } \\
\mathrm{i} \text { 2014? }\end{array}$ & $\begin{array}{l}\text { Er konventio- } \\
\text { nen inkorpo- } \\
\text { reret? }\end{array}$ \\
\hline $\begin{array}{l}\text { Den Europæiske Menneske- } \\
\text { rettigheds-konvention } \\
\text { (EMRK) }\end{array}$ & 1953 & $\mathrm{X}$ & $\mathrm{X}$ & $\mathrm{X}$ & \\
\hline $\begin{array}{l}\text { FN's konvention om borger- } \\
\text { lige og politiske rettigheder }\end{array}$ & 1971 & & $\mathrm{X}$ & & \\
\hline & & & & & \\
\hline
\end{tabular}

27 Zahle (2006) s. 364 ff.

${ }^{28}$ Egentlige konfliktsituationer er der ikke ifølge teorien noget klart svar på, medmindre der er tale om, at lovgivningsmagten bevidst har vedtaget regler, som man har været klar over stred mod konkrete konventionsmæssige forpligtelser. I en sådan - teoretisk - situation er litteraturen enige om, at den internationale ret må vige for den nationale ret. Alle andre mere ubevidste konflikter kan ikke Iøses ud fra enkle principper, idet der er forskellige opfattelser i teorien, og der heller ikke af retspraksis kan udledes klare retningslinjer.

${ }^{29}$ Efter betænkning nr. 1220/1991 om Den Europæiske Menneskerettighedskonvention og dansk ret, der forberedte inkorporeringen af EMRK, har man således drøftet yderligere inkorporeringer i Betænkning nr. 1407/2001 om Inkorporering af menneskerettighedskonventioner i dansk ret samt Betænkning nr. 1546/2014 om Inkorporering mv. inden for menneskerettighedsområdet. 


\begin{tabular}{|c|c|c|c|c|}
\hline $\begin{array}{l}\text { FN's konvention om } \varnothing \text { kono- } \\
\text { miske, sociale og kulturelle } \\
\text { rettigheder }\end{array}$ & 1971 & & & \\
\hline $\begin{array}{l}\text { FN's konvention om afskaf- } \\
\text { felse af racediskrimination }\end{array}$ & 1971 & $x$ & $x$ & \\
\hline $\begin{array}{l}\text { FN's konvention om forbud } \\
\text { mod tortur }\end{array}$ & 1987 & $x$ & $x$ & \\
\hline $\begin{array}{l}\text { FN's konvention om barnets } \\
\text { rettigheder }\end{array}$ & 1991 & & $x$ & \\
\hline FN's kvindekonvention & 1983 & & $x$ & \\
\hline FN's handicapkonvention & 2009 & & $x$ & $\begin{array}{l}\text { Er ikke inkor- } \\
\text { poreret, men } \\
\text { i kraft af ved- } \\
\text { tagelsen af } \mathrm{L} \\
221, \text { Folketin } \\
\text { get } 201718 \\
\text { sker en delvis } \\
\text { opfyldelse via } \\
\text { omskrivning }\end{array}$ \\
\hline
\end{tabular}

Som det fremgår af oversigten, har man efter inkorporeringen af EMRK i 1992 behandlet inkorporeringsspørgsmålet i betænkningerne fra henholdsvis 2001 og 2014. Udvalgene bag de to betænkninger anbefalede - i mere eller mindre enighed - yderligere inkorporeringer, men disse anbefalinger blev altså ikke fulgt op af politisk handling.

Særligt tydelig var modsætningen ved afgivelsen af betænkningen fra 2001, hvor et enigt udvalg anbefalede, at tre centrale menneskerettighedskonventioner skulle inkorporeres i dansk ret, nemlig FN's konvention om borgerlige og politiske rettigheder, FN's konvention om afskaffelse af alle former for racediskrimination og FN's konvention om forbud mod tortur. Kort tid efter betænkningens offentligg ørelse tiltrådte en ny regering, og den fandt ikke grundlag for at fremsætte lovforslag på baggrund af betænkningen. Konfronteret med et beslutningsforslag et godt stykke tid senere angav regeringen følgende begrundelse, som er relevant at hæfte sig ved, når spørgsmålet om betydningen af inkorporering skal vurderes:

"Regeringen har grundigt overvejet fordele og ulemper ved inkorporering af de nævnte konventioner, og regeringen er nået frem til, at man ikke vil følge Inkorporeringsudvalgets anbefaling. Det skyldes først 
og fremmest, at det ikke retligt vil gøre den store forskel, om FN-konventionerne inkorporeres i dansk ret eller ej. En inkorporering vil således først og fremmest have en mere symbolorienteret karakter." ${ }^{30}$

Tilkendegivelsen blev et par måneder senere fulgt op af følgende udtalelse ved behandlingen af et andet beslutningsforslag:

"FN-konventionerne er (...) allerede i dag en relevant retskilde i danske ret, og de anvendes af danske domstole og andre retsanvendende myndigheder, også selv om de ikke er inkorporeret i dansk ret. Når FN-konventionerne er relevante retskilder og anvendes af de danske domstole, finder regeringen det hverken retligt nødvendigt eller politisk hensigtsmæssigt at inkorporere konventionerne i dansk ret." ${ }^{31}$

Disse politiske udmeldinger er altså båret af et argument om, at inkorporering ikke indebærer nogen egentlig retlig forskel.

Da man omtrent et årti senere stod i en lignende situation, idet et nyt sagkyndigt udvalg i betænkningen fra 2014 anbefalede yderligere inkorporering af seks ud af de syv vurderede FN-konventioner, hvilket man fra regeringens side afviste at gøre, fremgik ikke nogen officielle politiske begrundelser ${ }^{32}$.

I en skriftlig kommentar til Berlingske Tidende oplyste justitsministeren imidlertid følgende:

"Som der også er givet udtryk for i udvalgets betænkning, vil inkorporering indebære en risiko for en forskydning af kompetence fra Folketinget og regeringen til domstolene. Og det er for regeringen vigtigt at fastholde de folkevalgtes ansvar for overholdelsen af vores internationale forpligtelser « ${ }^{33}$

Her supplerer man altså med argumentet om risikoen for magtforskydning fra lovgivningsmagten til domstolene, jf. nærmere nedenfor i afsnit 3.

Vender vi os fra de politiske begrundelser til de mere faglige synspunkter i betænkningerne, bliver billedet mere mudret. På den ene side kan man finde en række udsagn, der i tråd med det netop anførte giver indtryk af, at inkorporering ikke som sådan ændrer den pågældende internationale konventions retlige status. Således når det fx i Betænkning 1407 anføres, at

"Det er ikke alene konventioner, der er blevet gennemført i dansk ret ved omskrivning eller inkorporering, der er en relevant retskilde i dansk ret. Også konventioner m.m., der ikke er særskilt gennemført, idet der er blevet konstateret normharmoni, vil kunne påberåbes for og anvendes af danske domstole og andre retsanvendende myndigheder." 34

\footnotetext{
${ }^{30}$ Se 1. behandlingen af beslutningsforslag B 30 fra januar 2004 om inkorporering af FN's konvention om barnets rettigheder i dansk ret fremsat af Socialistisk Folkeparti.

${ }^{31}$ B 134 om inkorporering af FN-menneskerettighedskonventioner i dansk ret.

${ }^{32}$ Det kan dog bemærkes, at konklusionerne i denne betænkning var noget mere mudrede end i 2001, for udvalget var delt i sine afsluttende anbefalinger, og de medlemmer, der repræsenterede de forskellige ministerier, afholdt sig fra at deltage i de afsluttende anbefalinger, men forholdt sig neutralt. Det var således et relativt lille flertal, der anbefalede inkorporering af de 6 konventioner, jf. hertil også Jakob Mchangama fra tænketanken Justitia i Berlingske: https://mchangama.blogs.berlingske.dk/2014/08/15/inkorporering-af-menneskerettighedskonventioner-hv/ ${ }^{33}$ Berlingske, 22. november 2014: https://www.b.dk/politiko/regeringen-afviser-at-goere-fns-regler-til-dansk-lov

${ }^{34}$ Betænkning 1407/2001 s. 26.
} 
Helt lignende udtalelser fremgår også af den nyeste betænkning 1546 fra 2014, og træder måske særligt frem i de situationer, hvor nogle af udvalgsmedlemmerne argumenterer for, at der ikke bør inkorporeres yderligere, som fx her:

"Fire medlemmer af udvalget (Tina González-Schelbeck, Michael Hansen-Jensen, John Lundum og Hanne Schmidt) finder det vigtigt indledningsvist at understrege, at alle syv konventioner allerede $i$ dag er gældende for Danmark og for de flestes vedkommende har været det i mange år. Danmark er således folkeretligt forpligtet til at overholde konventionerne og til at indrette dansk lovgivning i overensstemmelse med konventionernes bestemmelser. Dette har også hidtil været efterlevet." ${ }^{35}$

Her får man skabt et billede af, at det ikke juridisk gør en egentlig forskel at inkorporere. Fortalerne for dette synspunkt er ikke afvisende over for, at inkorporering kan gøre en forskel, de mener bare ikke, at forskellen er af egentlig retlig karakter. Således fremhæves det i alle de sagkyndige betænkninger, at inkorporering kan have stor international signalværdi, og at der sker en tydeliggørelse af konventionens rettigheder og dermed en større bevidsthed herom ved såvel berørte borgere som retsanvendende myndigheder. ${ }^{36}$ Denne $\varnothing$ gede opmærksomhed kan i praksis give konventionen en øget betydning og dermed sikre en bedre retsbeskyttelse af borgerne, men det er altså ifølge disse synspunkter ikke så meget inkorporeringen i sig selv, der skaber denne potentielt forbedrede retstilstand.

På den anden side, kan man - hvis man går et spadestik dybere - spore en betydelig ambivalens i vurderingen af den retlige betydning af en inkorporering. For eksempel fremhæves det samtidigt, at "inkorporering vil skabe et lovbestemt grundlag for, at de retsanvendende myndigheder kan anvende konventionen" ${ }^{37}$ Og særligt i betænkning 1407/2001 tilføjes en række uddybende bemærkninger, der gør det tydeligt, at spørgsmålet er mere komplekst, og at et lovbestemt grundlag måske alligevel har retlige implikationer. Udvalget henleder for det første opmærksomheden på, at danske domstole ved flere lejligheder udtrykkeligt har fremhævet, at EMRK er blevet inkorporeret ved lov, og at disse bemærkninger må forstås således, at dette forhold har haft (retlig) betydning for domstolenes bedømmelse.

I forlængelse heraf anføres det, at det særligt er i tilfælde af konflikt mellem en national lovbestemmelse og en konventionsbestemmelse, at et egentligt lovgrundlag kan skabe større klarhed om retstilstanden. Udvalget skriver således:

"Selv om ikke-inkorporerede konventioner om menneskerettigheder må anses for at være en relevant retskilde i dansk ret, må det imidlertid efter udvalgets opfattelse være forbundet med en vis usikkerhed at forudsige, hvorledes danske domstole vil forholde sig i tilfælde af en konflikt mellem en bestemmelse i en lov og en ikke-inkorporeret konvention"38

Senere fremhæver man udsagnet om, at "konventionens status efter en inkorporering vil være åbenbar", hvilket blev fremført allerede i betænkning 1220/1991 og fortsætter:

"Herudover vil en inkorporering indebære, at domstolene og andre retsanvendende myndigheder får et lovbestemt grundlag for om nødvendigt at tilsidesætte en bestemmelse i en lov, som må anses for at

\footnotetext{
${ }^{35}$ Betænkning 1546 s. 11-12.

${ }^{36}$ Se Betænkning 1220/1991 s. 147, Betænkning 1407/2001 s. 129-143 og Betænkning 1546/2014 s. 97-107.

${ }^{37}$ Betænkning 1220/1991 s. 13-14 (med en lidt anden formulering), Betænkning 1407/2001 s. 140-141 og Betænkning $1546 / 2014$ s. $105-106$.

${ }^{38}$ Betænkning 1407/2001 s. 140.
} 
være i strid med en bestemmelse i en konvention, som er blevet inkorporeret ved lov. For så vidt angår de konventioner, der eventuelt måtte blive inkorporeret, vil en inkorporering ved lov dermed fjerne den usikkerhed, der i dag må antages at være med hensyn til løsningen af en sådan konflikt. Der kan således være tilfælde, hvor domstolene og andre retsanvendende myndigheder bl.a. vil skulle tage stilling til utilsigtede konflikter, og hvor de derfor vil have en korrigerende funktion"

Her får man altså klart givet udtryk for det synspunkt, at en inkorporering kan sikre konventionen en større retlig gennemslagskraft i de særlige situationer, hvor en dansk lovbestemmelse strider mod en konventionsbestemmelse, og hvor konflikten altså ikke kan bortfortolkes eller elimineres i den praktiske anvendelse, men hvor lovgivningsmagten på den anden side heller ikke udtrykkeligt og med åbne øjne har lovgivet i modstrid med konventionsforpligtelsen ${ }^{39}$.

\subsection{International ret i retspraksis}

Spørgsmålet er nu, om vi får mere klare svar om forholdet mellem national og international ret, når vi vender os mod domstolenes praksis. Svaret er nok nærmest både-og. På den ene side er der domme, der klart synes at bekræfte et relativt stringent dualistisk udgangspunkt. Mest markant er nok "aktiveringsdommen", UfR $2006.770 \mathrm{H}$, hvor en arbejdsløs mand havde rejst en sag med påstand om, at aktivlovens krav om aktivering stred imod en række af ILO's konventioner, altså en række konventioner, der var ratificeret og tiltrådt af Danmark, men som ikke var inkorporeret. I den forbindelse udtalte $\varnothing$ stre Landsret som en mere principiel betragtning, at "ILO's konventioner ikke er umiddelbart anvendelige i den forstand, at aktivlovens klare krav om deltagelse i aktivering som betingelse for at oppebære kontanthjælp ville kunne tilsidesættes, såfremt det antoges, at kravet var konventionsstridigt." Denne mere principielle betragtning tilsluttede Højesteret sig i den endelige dom, om end de ikke i den konkret sag fandt nogen modstrid mellem den danske lov og ILOkonventionerne.

En anden principiel udtalelse synes at falde i dommen om Irak-krigen ${ }^{40}$ og en eventuel overtrædelse af grundlovens $\S 19$. Her argumenterede sagsøgerne for, at FN-pagten ikke var overholdt, og at det burde have betydning for vurderingen af sagen, men $\mathrm{H} \varnothing$ jesteret afviste synspunktet og henviste blandt andet til "den grundlæggende ordning i dansk ret af forholdet mellem national ret og international ret, hvorefter folkeretten ikke har grundlovskraft".

På den anden side er er der efterhånden en del eksempler på, at internationale konventioner på forskellig vis og i forskelligt omfang inddrages af domstolene, og dette gælder vel at mærke ikke udelukkende den inkorporerede EMRK, men også andre menneskerettighedskonventioner. ${ }^{41}$ Det må dog bemærkes, at de ikke-inkorporerede konventioner overordnet set anvendes i langt mindre omfang end EMRK, og at den konkrete inddragelse har en langt mere overfladisk karakter. Således nøjes en del af de relevante domme med mere lakoniske konstateringer af, at de påberåbte internationale konventioner ikke kan føre til et andet resultat i den konkrete sag ${ }^{42}$.

Som det også fremgår af de citerede domme overfor, kompliceres et mere samlet billede af betydningen af internationale menneskerettighedskonventioner af, at situationen ikke for alvor har været sat på spidsen i

\footnotetext{
39 Dette er i øvrigt også synspunktet hos Jens Elo Rytter, 2016, s. 61.

40 UfR $2010.1547 \mathrm{H}$

${ }^{41}$ Se for en oversigt: Betænkning 1546/2014, s. 50-78

${ }^{42}$ Se fx U 2012.2835 Ø og U 2014.214 Ø.
} 
retspraksis. Der har således endnu ikke været situationer, hvor domstolene har skullet bedømme sammenst $\varnothing$ det mellem en klar national lovregel og en ikke-inkorporeret international konvention.

I forhold til den inkorporerede EMRK synes domstolene at have anlagt en mere integrerende stil ud fra et grundsynspunkt om, at EMRK som udgangspunkt har forrang for den almindelige lovgivning ${ }^{43}$, og at loven eller den administrative forskrift skal tilpasses konventionen i den konkrete retsanvendelse ${ }^{44}$. Helt håndfaste konklusioner svækkes imidlertid af, at man et langt stykke hen af vejen har foretaget tilpasningen til EMRK via fortolkningsvejen, altså ved at strække fortolkningen af national ret langt. ${ }^{45}$ Heller ikke her synes der således at være gode eksempler på, at danske domstole har tilsidesat klare lovbestemmelser, der strider mod EMRK.

Det er imidlertid værd at bemærke sig, at retspraksis indeholder en del eksempler på, at danske domstole har underkendt konkrete afgørelser eller adfærd med direkte henvisning til, at disse måtte anses som stridende mod grundlæggende menneskerettigheder i EMRK. Af illustrative eksempler kan for eksempel nævnes en række sager om udvisning af udlændinge omkring årtusindeskiftet ${ }^{46}$, domstolenes underkendelse af en række frihedsberøvelser i forbindelse med COP15-topmødet som ulovlige og stridende mod EMRK ${ }^{47}$ samt nyere højesteretsdomme, der har erklæret forholdene for udlændinge på tålt ophold for stridende mod EMRK's bestemmelser om retten til privat- og familieliv ${ }^{48}$.

Det er imidlertid også et gennemgående karakteristikum, at domstolene foretager en mere tilbageholdende prøvelse ${ }^{49}$, og ofte gør det med henvisning til respekt for magtfordelingen mellem lovgivningsmagten og domstolene. Dette har $\mathrm{fx}$ betydet, at man ved mere generelle konflikter mellem national lovgivning og EMRK har afholdt sig fra direkte at underkende i den konkrete sag, men i stedet eksplicit henvist spørgsmålet til afklaring ved lovgivningsmagten, som fx da Højesteret i 1994 anså det for tvivlsomt, om ordningen med konstituerede dommere var i overensstemmelse med EMRK art. $6 .{ }^{50}$ Det har også betydet, at danske domstole er tilbageholdende med at anlægge selvstændige fortolkninger af konventionen ${ }^{51}$ og derfor som udgangspunkt kun vil statuere konventionskrænkelse, hvis der foreligger retspraksis fra Den Europæiske Menneskerettighedsdomstol, der forholder sig mere direkte til den relevante problemstilling ${ }^{52}$.

\footnotetext{
${ }^{43}$ Her har diskussionerne i teorien snarere gået på, i hvor vid udstrækning domstolene er bundet af EMD' retspraksis i deres konkrete udlægning af EMRK-forpligtelserne, og særligt om inkorporeringen i 1992 betyder, at det kun er EMDpraksis fra før 1992, eller om inkorporeringen omfatter hele traktatkomplekset, altså både EMRK og tilhørende retspraksis, som den til enhver tid er udlagt af Den Europæiske Menneskerettighedsdomstol. Se hertil fx Garde og Jessen i Juristen 1998, s. 351 ff og Jens Vedsted-Hansen i Festskrift om Menneskerettigheder til Carl Aage Nørgaard, 2004 s.

$384 \mathrm{ff}$ og Jens Elo Rytter, anf. arb., 2016, s. 54 f.

${ }^{44}$ Se for en glimrende oversigt over retspraksis (dog kun indtil 2001), Betænkning 1407/2001, s. $36 \mathrm{ff}$.

45 Jf. Betænkning 1407/2001 s. 56 ff og Betænkning 1546/2014 s. 47 ff.

${ }^{46}$ Se fx UfR 2000.1499 H, UfR 2002.736 H og UfR 2002.1411 H.

${ }^{47}$ UfR $2012.1439 \varnothing$

${ }^{48}$ UfR 2012.2874 H og UfR 2017.1228 H.

49 Jf bl.a. Jens Elo Rytter, 2016, s. 58.

50 UfR $1994.536 \mathrm{H}$

${ }^{51}$ Se for en kritisk analyse direktivet om tilbageholdenhed i forarbejderne til den danske EMRK-inkorporeringslov: Bardur Larsen: Kan dømmekraften underlægges regler? i TfR vol. 128, 5/2015, s. 405-436.

52 Jf. fx
} 
Et yderligere pres i den retning er opstået med diskussionen af og indførelsen af eksplicitte sikkerhedsdoktriner i den menneskeretlige regulering på særligt udlændingeområdet. Således fremgår det nu af udlændingelovens $\S 26$, stk. $2^{53}$, at udvisning skal ske, "medmindre det med sikkerhed er i strid med Danmarks internationale forpligtelser" ${ }^{54}$, hvilket kan være en af årsagerne ${ }^{55}$ til, at vi for ganske nyligt har set en del eksempler på, at $\mathrm{H} \varnothing j$ jesteret ikke har underkendt, men blåstemplet en række udvisninger i en menneskeretlig gråzone ${ }^{56}$.

\section{6 Opsamling}

Diskussionerne om betydningen af international ret i dansk ret er modsætningsfyldte. På den ene side har litteraturen i en lang årrække primært grebet problemstillingen an som et retsteoretisk spørgsmål inspireret af retsfilosofiske og retskildemæssige overvejelser om dualisme og monisme og udledt deraf følgende principper om fortolknings-, formodnings- og instruktionsreglen. Nyere forfattere har i højere grad integreret praksis i deres fremstillinger af betydningen af international ret, men uden at dette nødvendigvis har givet grundlag for klarere slutninger om konventioners status. Og med praksis menes i altovervejende grad domstolspraksis. Administrativ praksis betragtes kun i meget begrænset omfang som relevant, og ingen har hidtil for alvor rettet opmærksomheden mod lovgivningsmagtens praksis.

Diskussionerne om betydningen af inkorporering gør os ikke så meget klogere på, hvordan de $\emptyset$ verste statsorganer ser på spørgsmålet om international rets betydning, for der har været noget modstridende udmeldinger i officielle betænkninger og fra skiftende regeringer. Når man skal begrunde og forsvare en manglende inkorporering henviser man til, at de relevante konventioner allerede er gældende som om de var inkorporeret, mens man dog samtidigt erkender, at inkorporering giver et mere tydeligt retligt grundlag og kan indebære en magtforskydning fra lovgivningsmagt til domstole.

Heller ikke retspraksis giver klare bidrag til diskussionerne om forholdet mellem national og international ret i Danmark. Der synes at være tegn på, at inkorporerede konventioner symbolsk og reelt spiller en mere vægtig retlig rolle i den konkrete retsanvendelse end andre internationale menneskerettighedskonventioner, idet EMRK kan have afgørende betydning for udfaldet af konkrete sager. Til gengæld er der intet, der peger i retning af en mere selvstændig og retsskabende domstolsrolle i sagerne om international ret, idet den samlede retspraksis giver indtryk af, at danske domstole efterlever det direktiv om tilbageholdenhed, som de er blevet pålagt af regering og folketing.

\footnotetext{
${ }^{53}$ Formuleringen blev oprindeligt indført i 2011 (L 210, Folketinget 2010-11), afskaffet af den socialdemokratisk ledede regering i 2012, og genindført af den borgerlige regering i 2017 ved L 49, Folketinget 2016-17.

${ }^{54}$ Se for en kritisk analyse Jens Vedsted-Hansen: "Med sikkerhed i strid med internationale forpligtelser" - om EU-ret og andre regler som politisk handelsobjekt i "Festskrift til Nis Jul Clausen", DJØF 2013.

${ }^{55}$ Dog er det formentlig også af betydning, at der opstod en faglig debat om, hvorvidt EMRK art. 8 reelt var en hindring for udvisning i mange af de sager, hvor Danmark ønskede at udvise, jf. udtalelserne fra Jonas Christoffersen på Altinget: https://www.altinget.dk/christiansborg/artikel/jonas-christoffersen-danmark-kan-udvise-flere-for-grov-kriminalitet, som er baseret på følgende analyse fra Institut for Menneskerettigheder: https://menneskeret.dk/sites/menneskeret.dk/files/media/dokumenter/udgivelser/udvisning af kriminelle udlaendinge analyse 2017.pdf

${ }^{56}$ Se fx Højesterets dom afsagt 24. maj 2018 i sag 42/2018, Højesterets dom afsagt 19. november 2018 i sag $124 / 2018$ og Højesterets dom afsagt 20. november 2018 i sag 81/2018.
} 


\section{Diskussionen om magtforholdet mellem regering/FT og domstole}

Som det allerede er fremgået, har det har været et helt afgørende omdrejningspunkt i de danske diskussioner om betydningen af internationale ret, at magtforholdet mellem domstolene og lovgivningsmagten ikke må forrykkes i den forstand, at domstolene får en mere betydningsfuld rolle i implementeringen af international ret. Synspunktet bliver både gjort gældende i de officielle betænkninger, og når man fra politisk hold har argumenteret for risikoen ved yderligere inkorporeringer. I det følgende skal undersøges, hvad der mere konkret ligger i magtforskydningsargumentet. Synspunktet fremføres første gang i inkorporeringsbetænkningen fra 1991, s. 113, hvori det hedder:

"En anden indvending af mere principiel karakter vedrører spørgsmålet om forholdet mellem domstolene og lovgivningsmagten. En inkorporering kan medføre, at ansvaret for den løbende opfyldelse af konventionen i højere grad overlades til domstolene, således at lovgivningsmagten fratages incitamentet til selv at justere lovgivningen i lyset af en afgørelse fra Domstolen. En sådan udvikling kan være betænkelig, fordi den skaber tvivl om, hvilken af flere mulige fortolkninger af en konventionsbestemmelse eller eventuelt en dom der skal lægges til grund ved bedømmelsen af et retsforhold for en dansk domstol. Dette valg vil kunne være af mere politisk karakter og bør derfor træffes af lovgivningsmagten. Endvidere risikerer man, at forrykke balancen mellem domstolene og lovgivningsmagten, idet domstolene overlades en kontrolopgave, der ligger uden for, hvad de normalt påtager sig"

Her fremgår det altså, at det først og fremmest er risikoen for, at inkorporering bliver en sovepude for lovgivningsmagten, så man ikke i tilstrækkelig grad får justeret lovgivningen i lyset af nye praksis, man er optaget af. Hvis ikke lovgivningsmagten tager stilling til og tilretter lovgivningen løbende, kan domstolene være $n \varnothing \mathrm{dt}$ til at afgøre fortolkningsspørgsmålene, hvilket kan indebære mere politisk betonede valg.

Med formuleringen "en kontrolopgave, der ligger uden for, hvad de (domstolene, red.) normalt påtager sig" refereres til den danske tradition for en tilbageholdende domstolskultur. Danske domstole vil normalt være forsigtige i deres prøvelse af sager, der indebærer politiske valg af mere vidtrækkende karakter og i sådanne sager afvise at påtage sig en mere retsskabende rolle ${ }^{57}$. Og i sager om loves grundlovsmæssighed har man opereret med en sikkerhedsdoktrin, således at lovgivningen kun underkendes, hvis grundlovsstridigheden fremgår med en vis sikkerhed ${ }^{58}$. I grundlovssagerne har man ofte begrundet doktrinen med, at det er meget vanskeligt at ændre den danske grundlov ${ }^{59}$, hvorfor en aktiv domstol reelt sætter lovgiver skakmat og i stedet selv agerer som (grund)lovgiver. Samme ræsonnement kan også gøres gældende i forhold til internationale konventioner, hvor konsekvenserne af en retsskabende domstol kan være vidtrækkende, fordi lovgivningsmagten ikke selv har mulighed for at korrigere den internationale konvention, der i sagens natur har en lang række kontraherende parter.

Den citerede indvending om risiko for magtforskydning fik ikke 1991-udvalget til helt at fraråde inkorporering af EMRK. Men det anføres til gengæld som en vigtig præmis for udvalgets anbefaling af inkorporering, at

\footnotetext{
57 Jf. fx Jens Peter Christensen: Domstolene - den tredje statsmagt, 2003, s. 39

${ }^{58}$ Se fx Jens Peter Christensen et. al.: Dansk statsret, 1. udgave 2012, s. $251 \mathrm{ff}$.

59 Ibid., s. 255
} 
Højesteret fortsætter sin hidtidige tilbageholdende selvstændige fortolkning af konventionen ${ }^{60}$, således at $\mathrm{H} \varnothing$ jesteret henskyder mere politiske valg til lovgivningsmagten. ${ }^{61}$

De kommende år bidrager ikke yderligere til afklaring af temaet, men magtforskydningsargumentet bruges flittigt og fastslås også ved betænkning 1407/2001. I den nyeste inkorporeringsbetænkning fra 2014 tilføjes imidlertid nogle nuancer. Det anføres nemlig, at risikoen for magtforskydning navnlig kan blive aktuelt, hvis eventuelt inkorporerede konventioner pålægger staten positive forpligtelser. Særligt ét sted i teksten bliver udvalget meget specifik i sin udfoldelse af problematikken:

"Hvis FN-konventionernes bredt formulerede bestemmelser inkorporeres ved lov og dermed bliver en umiddelbar del af dansk ret, skabes herved et stærkere grundlag for at anvende konventionsbestemmelserne i overensstemmelse med komitéernes udtalelser, hvilket indebærer en ikke ubetydelig risiko for, at danske domstole vil komme til at træffe afgørelse vedrørende spørgsmål, herunder fordelingspolitiske spørgsmål, som det efter dansk forfatningstradition tilkommer lovgivningsmagten at træffe." 62

Det er for så vidt interessant, at selv om det altså ifølge citatet særligt er ved de bredt formulerede bestemmelser om $\mathrm{fx} \varnothing$ konomiske og sociale rettigheder, at risikoen for uhensigtsmæssig magtforskydning til domstolene er til stede, fastholdes fortsat det generelle fortolkningsdirektiv om domstolstilbageholdenhed.

Derudover er det karakteristisk, at den inkorporeringsskeptiske del af udvalget vender tilbage til det oprindelige hovedargument, da de skal begrunde, hvorfor de fraråder yderligere inkorporering:

"For det tredje indebærer inkorporering dog samtidig en risiko for, at der sker en forskydning af kompetence fra Folketinget til regeringen, der har hovedansvaret for at tage stilling til og gennemføre internationale konventioner i dansk ret, til domstolene og andre retsanvendende myndigheder (min fremhævning)." 63

Det ligger altså som en helt afgørende præmis for argumentet for at undlade inkorporering, at det vil svække lovgivningsmagtens løbende opmærksomhed på konventionsforpligtelserne. Ellers sagt på anden vis: Direktivet om domstolstilbageholdenhed hviler på den vigtige forudsætning, at lovgivningsmagten løbende foretager en mere nidkær vurdering og implementering af de internationale menneskerettighederl det følgende skal derfor foretages en analyse af, på hvilken nærmere måde lovgivningsmagten har inddraget konventionsforpligtelser i de senere år. Af praktiske årsager fokuseres på lovgivningsprocesser fra folketingsåret 2014-15 og fremefter.

\section{Analyse af centrale nyere lovforarbejder}

Det følgende er baseret på en række nyere lovforslag med tilhørende bemærkninger, der alle på mere afg $\varnothing$ rende vis aktualiserer menneskeretlige problemstillinger, hvorfor forholdet til international ret er relevant

\footnotetext{
${ }^{60}$ For en kritik af dette fortolkningsdirektiv til domstolene, se Bardur Larsen: Kan dømmekraften underlægges regler kritiske refleksioner omkring forarbejderne til den danske lov om inkorporering af Den Europæiske Menneskerettighedskonvention, Tidsskrift for Rettsvitenskap 05/2015, s. 405-436.

61 Jf. Betænkning 1220/1991 s. 14 og s. 81.

62 Jf. Betænkning 1546/2014 s. 12

63 Ibid.
} 
og i forskelligt omfang adresseres af regeringen. Lovforslagene dækker perioden $2015-2018^{64}$ og er fra folketingssamlingerne 2014-15 (3 lovforslag), 2015-16 (3 lovforslag), 2016-17 (7 lovforslag) og 2017-18 (5 lovforslag).

Lovforlagene er udvalgt ved hjælp af en screening af Folketingets dokumentsamling kombineret med årlige oversigter fra Institut for Menneskerettigheder (Danmarks Nationale Menneskerettighedsinstitution ${ }^{65}$ ), over vigtige begivenheder i den menneskeretlige udvikling i Danmark. Fremgangsmåden og de metodiske overvejelser kan skitseres på følgende vis:

En systematisk elektronisk søgning i Folketingets dokumentsamling for den pågældende periode giver en stor bruttoliste af lovforslag, der ikke alle kan undergives nærmere analyse, og som heller ikke alle er lige relevante. Konkret blev der anvendt søgeordene "internationale forpligtelser", "internationale konventioner" og "EMRK", og søgningen var i hele lovforslagets tekst ved fremsættelsen (inkl. bemærkninger), og ikke blot i overskrift eller resumé. Den vigtigste grovsortering og udvælgelse af lovforslag fremkom derfor ved at tage fat i de årlige statusrapporter, som Institut for Menneskerettigheder udarbejder over vigtige begivenheder i den menneskeretlige udvikling i Danmark. IMR fungerer som uafhængig sagkyndigt institut, der som led i deres rolle som "National Menneskerettighedsinstitution" gennemser alle potentielt relevante lovforslag ud fra et menneskerettighedsperspektiv og afgiver eventuelle høringssvar. Der er således grund til at antage, at IMR har et kvalificeret overblik over de centrale menneskeretlige lovforslag for en given periode.

En fordel ved at kombinere bruttosøgningen i Folketingets dokumentsamling med IMR's årsberetninger var, at der også blev samlet enkelte lovforslag op, som enten slet ikke fremgik af den elektroniske søgning eller kun så ud til at være et søgeresultat af mere perifer karakter, fordi regeringen i lovforslaget ikke (eller kun ganske overfladisk) nævnte menneskeretlige problemstillinger, som efter Institut for Menneskerettigheders opfattelse var ganske centrale ${ }^{66}$.

Som en mere metodisk overvejelse kan dog nævnes, at de årlige statusberetninger fra IMR kan siges at anlægge et mere problembaseret perspektiv og fokusere på de lovforslag, hvor de menneskeretlige udfordringer er størst. Man kan med andre ord stille spørgsmålet, om de udvalgte lovforslag giver et repræsentativt billede af regeringens håndtering af international ret i den pågældende periode.

For at tage højde for denne indvending vendte jeg tilbage til bruttosøgningen på Folketingets digitale dokumentsamling og foretog et ekstra tjek af lovforslagene fra søgeresultatet sorteret efter relevans. I den forbindelse gik jeg en gruppe lovforslag igennem for at vurdere, om de burde inddrages supplerende som grundlag for artiklens analyse. En ganske stor del af disse blev fravalgt, enten fordi det menneskeretlige aspekt viste sig at være helt sporadisk, eller fordi lovforslaget blev vurderet at udgøre et særtilfælde, fordi der fx var

\footnotetext{
${ }^{64}$ Dog med en skæringsdato 15. april 2018, således at lovforslag fremsat efter denne dato ikke er inddraget i analysen. 65 IMR er som National Menneskerettighedsinstitution en uafhængig statsfinansieret institution, der skal beskytte og overvåge menneskerettighedssituationen i Danmark, se https://menneskeret.dk/om-os ${ }^{66}$ Der er tale om L 215, Folketinget 2016-17, om skærpelse af straffen for utryghedsskabende tiggeri og L 146, Folketinget 2016-17 om FE's adgang til oplysning om flypassagerer og ændring af FE's forpligtelse til sletning af oplysninger.
} 
tale om gennemførelse af en EU-forordning eller et EU-direktiv ${ }^{67}$, eller fordi der var tale om en indfødsretslov $^{68}$. Men tilbage var også en lille bunke lovforslag, som jeg besluttede jeg at inddrage supplerende, og som kommer til at fungere som en nuancering af analysens hovedpointer, jf. nærmere under punkt 4.6 nedenfor.

Inden den egentlige analyse er der anledning til at anføre nogle få generelle bemærkninger om Danmarks tilrettelæggelse af det lovforberedende arbejde i relation til internationale konventionsmæssige forpligtelser. Som allerede nævnt har Danmark ikke et egentligt lovråd eller et særligt parlamentsudvalg, der har til opgave at vurdere og udtale sig om lovforslagenes forhold til grundloven og internationale konventioner ${ }^{69}$. På lovens forberedelsesstadium er den eneste screenings- eller vurderingsproces, der foretages, således ministeriernes egen, der i de mere vanskelige sager normalt vil blive overladt til Justitsministeriets Lovafdeling. Folketinget er på den baggrund ganske afhængig af de analyser, regeringen får foretaget i centraladministrationen, men kan eventuelt supplere sin viden med de høringssvar, som IMR udarbejder, når lovforslagene er fremsat for Folketinget. Instituttets høringssvar til de forskellige lovforslag inddrages også i forskelligt omfang i den følgende analyse.

\subsection{Restriktiv relevanspraksis}

Den danske regering har en relativ snæver opfattelse af, hvilke internationale konventioner der er anledning til at forholde sig til i forbindelse med behandling af lovforslag. De analyserede lovforslag tegner således et klart billede af, at det som altovervejende hovedregel kun er Den Europæiske Menneskerettighedskonvention, der inddrages i lovforslagenes afsnit om forholdet til Danmarks internationale forpligtelser. Dette gælder, også selv om der eksisterer andre konventionsmæssige forpligtelser af relevans for lovforslagets indhold.

Eksempelvis kan peges på lovforslag nr. L 219 af 11. april 2018 om det såkaldte tildækningsforbud; en ændring af straffeloven, som forhindrer tildækkende klædedragter af fx religiøs karakter. Her vurderer Justitsministeriet i lovbemærkningernes afsnit om internationale forpligtelser lovforslagets forhold til EMRK art. 8, 9, 10 og 14, mens man for eksempel ikke nævner eller overvejer lovforslagets forhold til andre relevante internationale konventioner, som FN's konvention om borgerlige og politiske rettigheder eller FN's kvindekonvention. ${ }^{70}$ Et andet eksempel er lovforslag nr. L 18 af 5. oktober 2016, som kriminaliserer visse udtalelser fra religiøse forkyndere. Ud over forholdet til grundloven vurderes udelukkende EMRK og ikke fx FN's konvention om borgerlige og politiske rettigheder, selv om forslaget berører centrale rettigheder som ytringsog religionsfrihed. Regeringen opretholder ofte med sin sprogbrug en forestilling om, at der foretages en bredere konventionsmæssig vurdering, idet man anfører, at "forslaget er navnlig vurderet i forhold til bestemmelserne om religionsfrihed og ytringsfrihed samt forbuddet mod diskrimination i grundloven og Den Europæiske Menneskerettighedskonvention (EMRK)" og senere: "Det er samlet set Justitsministeriets vurdering, at lovforslaget vil kunne gennemføres inden for rammerne af grundloven og Danmarks internationale forpligtelser, herunder EMRK." (mine fremhævninger) ${ }^{71}$ Men når det kommer til stykket, specificeres eller behandles disse konventioner ikke.

\footnotetext{
${ }^{67}$ Fx L 126, Folketinget 2061-17, og L 125, Folketinget 2017-18 samt L 149, Folketinget 2016-17.

${ }^{68}$ Fx L 44, Folketinget 2014-15, 1. samling.

${ }^{69}$ Se hertil Pernille Boye Koch: Forfatningskontrol, DJØF's forlag, 2002.

${ }^{70}$ L 219, Folketinget 2017-18, s. 6-8 og IMR's høringssvar af 6. marts 2018.

${ }^{71} \mathrm{~L} 18$, Folketinget $2016-17$ s. 4 og s. 7.
} 
Der er dog enkelte undtagelser til denne tendens. Et sådant tilfælde udgør L 87 af 10. december 2015 om ændring af udlændingeloven, som var et stort lovkompleks fremsat og vedtaget midt i den såkaldte flygtningekrise, og som blandt andet udskød retten til familiesammenføring for personer med midlertidig beskyttelsesstatus og skærpede reglerne om tidsubegrænset opholdstilladelse og reglerne om flygtninges opholdstilladelse. Ud over forholdet til EMRK ser vi her lovbemærkningerne ${ }^{72}$ belyse forholdet til FN's børnekonvention, FN's handicapkonvention og Flygtningekonventionen. ${ }^{73}$ Men dette tilfælde kan beskrives som undtagelsen, der bekræfter reglen ${ }^{74}$.

Den snævre relevanspraksis ses også afspejlet i det faktum, at det relevante ministerium for nogle lovforslags vedkommende slet ikke omtaler forholdet til international ret, selv om det kan siges at være relevant. Det gælder fx lovforslag nr. L 215 af 2. juni 2017 om skærpelse af straffen for utryghedsskabende tiggeri, hvor forholdet til Danmarks internationale forpligtelser er helt uomtalt i lovbemærkningerne, selv om forslaget aktualiserer spørgsmål om forholdet til både FN's konvention om Økonomiske, Sociale og Kulturelle Rettigheder og EMRK. ${ }^{75}$ Det gælder også lovforslag nr. L 146 af 9. februar 2018 om ændring af sundhedsloven, der bl.a. omfatter oprettelsen af et Nationalt Genom Center. Her forholder lovbemærkningerne sig kun til forholdet til EU's databeskyttelsesforordning, mens man slet ikke vurderer spørgsmålet om overensstemmelse med fx EMRK art. 8 om beskyttelse af privat- og familieliv. ${ }^{76}$

Endelig ses eksempler på, at det kun er dele af et lovforslag, hvis forhold til international ret vurderes, mens andre måske mindre fremtrædende dele af lovforslaget ignoreres, selv om disse dele også aktualiserer menneskeretlige spørgsmål. Et eksempel herpå er lovforslag nr. L 146 af 24. februar 2017 om ændring af lov om Forsvarets Efterretningstjeneste (FE) og toldloven. Her blev lovforslagets dominerende indhold; nemlig efterretningstjenestens udvidede beføjelser til at få adgang til oplysninger om flypassagerer, undergivet en relativt grundig vurdering i forhold til internationale forpligtelser, mens den anden del af forslaget, en reduceret pligt for Forsvarets Efterretningstjenestes til at slette irrelevante personoplysninger, slet ikke blev bedømt i forhold til menneskerettighederne, selv også denne del klart aktualiserer spørgsmål om overholdelse af EMRK art. $8^{77}$.

\subsection{Indskrænket proportionalitetsvurdering ${ }^{78}$}

\footnotetext{
72 Se Lovforslag nr. L 87, Folketinget 2015-16, de almindelige bemærkninger, fx afsnit 2.2.2 og afsnit 5.5.

${ }^{73}$ Det fremgår dog af IMR's høringssvar, at ministeriet ikke har inddraget alle de internationale konventioner, som efter instituttets opfattelse er relevante, og endvidere at den menneskeretlige vurdering ikke er meget udførlig. Se nærmere herom IMR's høringssvar af 6. januar 2016.

${ }^{74}$ Det er det eneste af de i alt 17 analyserede lovforslag, der foretager en udførlig behandling af andre internationale forpligtelser end EMRK. Dog nævnes FN's Handikapkonvention i yderligere 2 lovforslag, men uden at der foretages nogen form for realitetsbehandling af forholdet til denne konvention (se fx lovforslag L 2, Folketinget 2014-15, 2. samling, s. $14 \varnothing$ verst).

${ }^{75}$ Se IMR's høringssvar af 9. juni 2017.

76 Jf. også IMR's høringssvar af 13. oktober 2017.

77 Jf. Lovforslag nr. L 146, Folketinget 2016-17, de almindelige bemærkninger.

${ }^{78}$ Det kan generelt anføres, at denne analyse ikke har til formål at foretage en egentlig materiel bed $\varnothing \mathrm{mmelse}$ af den i lovbemærkningerne anførte bedømmelse af forholdet til international ret, herunder EMRK. Det falder uden for rammerne af denne artikels fokus. På den baggrund vurderes heller ikke fx om indgrebene varetager et legitimt formål og er saglige og proportionale. Min fokus i dette afsnit om proportionalitetsvurderingen er således alene at illustrere, hvorvidt og i hvilket omfang lovforslagene lever op til de mere formelle krav om en proportionalitetsvurdering.
} 
Det er et afgørende element, når man skal vurdere konkrete initiativer i forhold til Den Europæiske Menneskerettighedskonvention, at der foretages en proportionalitetsvurdering ${ }^{79}$, altså en afvejning af det konkrete indgreb i den beskyttede rettighed i forhold til det mål, samfundet gerne vil opnå ved lovgivningsinitiativet. Indgrebet skal være nødvendigt i et demokratisk samfund, og "der foretages i EMD's afgørelser ofte en detaljeret og særdeles konkret vurdering af, om Staten efter en samlet vurdering af alle omstændigheder har overskredet grænserne for, hvad der kan betegnes som en 'fair balance' mellem individets rettigheder og modstående interesse" ${ }^{\prime 80}$. Dette indebærer blandt andet, at indgrebet skal være begrundet i et påtrængende samfundsmæssigt behov ("pressing social need"), at det skal være egnet og nødvendigt for at opnå formålet, at individets frihed er udgangspunktet, og at der skal udvises særlig tilbageholdenhed ved indgreb i fundamentale rettigheder og særligt intensive indgreb i rettighedens kerne. ${ }^{81}$

På den baggrund vil det ofte være et obligatorisk element i regeringens argumentation for, at et givent lovforslag ikke udgør et problem i forhold til international ret, at gennemføre en sådan konkret proportionalitetsvurdering. Når de seneste års lovforslag studeres, er det imidlertid et gennemgående karakteristikum, at proportionalitetsvurderingen oftest er meget sporadisk og nogle gange får nærmest postulerende karakter. ${ }^{82}$

Et illustrativt eksempel er lovforslag nr. L 48 af 9. november 2016 om ændring af udlændingeloven (Indførelse af en offentlig sanktionsliste over udenlandske religiøse forkyndere m.fl., som kan udelukkes fra indrejse). ${ }^{83}$ Her skriver ministeriet $f x$ følgende i relation til EMRK art. 9 om religionsfrihed:

"For så vidt angår indgrebets proportionalitet, bemærkes det, at Domstolen har fastslået, at EMRK art. 9 ikke giver personer, der følger sin religiøse overbevisning, en ret til at se bort fra lovgivning, der forfølger saglige hensyn, jf. præmis 121 i sagen Leyla Sahin mod Tyrkiet, dom af 10. november 2005.

Udlændinge-, Integrations- og Boligministeriet finder, at det vil være sagligt og proportionalt at forhindre udlændinge, der virker som religiøse forkyndere eller på anden måde udbreder en religion eller tro, $\mathrm{i}$ at indrejse her i landet, når hensynet til den offentlige orden i Danmark tilsiger, at udlændingen ikke bør have ophold her i landet på grund af adfærd, herunder ytringer, der er udvist i sammenhæng med udlændingens virke som religiøs forkynder mv.

Ministeriet har herved bl.a. lagt vægt på, at personer, der virker som religiøse forkyndere eller på anden måde udbreder en religion eller tro, har en særlig position i forhold til at påvirke deres menighed mv. og herved en særlig position i forhold til f.eks. at fremkalde en forstyrrelse af den offentlige orden.

På den baggrund er det Udlændinge, Integrations- og Boligministeriets opfattelse, at den foreslåede ordning er forenelig med EMRK art. 9." 84

\footnotetext{
${ }^{79}$ Se fx Peer Lorenzen m.fl. (red.): Den Europæiske Menneskerettighedskonvention med kommentarer bind 1, 3. udgave 2011, s. $30 \mathrm{ff}$.

80 lbid.

${ }^{81}$ Se Jens Elo Rytter: Individets grundlæggende rettigheder, 2. udgave, 2018, s. $100 \mathrm{ff}$.

82 I overensstemmelse hermed er det klart mest fremhævede kritikpunkt, der går igen i stort alle høringssvarene fra Institut for Menneskerettigheder, at "ministeriet bør foretage en grundigere proportionalitetsafvejning af den foreslåede bestemmelse i lyset af, at der foretage indgreb i fundamentale rettigheder", her citeret fra IMR's høringssvar af 11. juli 2016 over udkast til lovforslag om ændring af straffeloven.

83 Jf. Lovforslag nr. L 48, Folketinget 2016-17.

84 Jf. s. 33-34 i lovforslagets almindelige bemærkninger.
} 
Selv om bemærkningerne deklareres som en proportionalitetsvurdering, er det ved nærmere eftersyn vanskeligt at karakterisere dem som sådanne. I det første afsnit af det citerede refereres der til det principielle udgangspunkt, der kan udledes af EMD's praksis, om at man ikke kan bruge sin religiøse overbevisning som begrundelse for at se bort fra lovgivning, der i $\varnothing$ vrigt er begrundet i saglige hensyn. Næste afsnit er en erklæring af, at det efter ministeriets opfattelse vil være sagligt og proportionalt at gennemføre lovforslagets indhold, altså snarere en påstand end en argumentation. Det tætteste, man kommer en mere konkret vurdering, er derfor i det tredje afsnit, der henviser til, at de religiøse forkyndere har en særlig position i forhold til fx at fremkalde en forstyrrelse af den offentlige orden. Men dette kan ikke siges at være udtryk for en proportionalitetsafvejning, for taget for pålydende kunne synspunktet jo være et argument for, at man kunne foretage sig hvad som helst over for sådanne religiøse forkyndere, fordi de har en sådan særlig position.

Der findes imidlertid også eksempler på lidt mere reelle og udførlige proportionalitetsvurderinger. For eksempel kan peges på lovforslag nr. L 35 af 4. oktober 2017 om ændring af straffeloven, lov om en børne- og ungeydelse og lov om børnetilskud og forskudsvis udbetaling af børnebidrag, som blandt andet udvidede mulighederne for at id ømme bandekriminelle opholdsforbud efter endt afsoning, altså forbud mod at færdes eller opholde sig i bestemte områder. Her hedder det om proportionalitetsvurderingen blandt andet følgende:

\begin{abstract}
"Ministeriet har herved lagt vægt på, at opholdsforbuddet, herunder den tidsmæssige og geografiske udstrækning af forbuddet, idømmes af domstolene på baggrund af en konkret vurdering, og at forbuddet idømmes som led i en straffedom for alvorlig kriminalitet, som har baggrund i en voldelig konflikt mellem grupper, eller for kriminalitet, som har relation til den pågældendes tilknytning til en gruppe, der tilsammen står bag omfattende og alvorlig kriminalitet. Der gør sig i sådanne sager om bl.a. rockerog bandekriminalitet særligt tungtvejende hensyn gældende til at mindske risikoen for recidiv og negativ resocialisering og til at beskytte omgivelserne mod de store gener, som kriminaliteten genererer. Der er herved lagt vægt på, at der er en direkte sammenhæng mellem forbuddets geografiske udstrækning og det eller de steder, hvor kriminaliteten er begået, eller hvor den gruppe, som kriminaliteten har tilknytning til, opholder sig. Opholdsforbuddet må af samme årsag anses for egnet til at varetage hensynene bag forbuddet, da den pågældende fjernes fra området.

Ministeriet har endvidere lagt vægt på, at forbuddet ikke indskrænker den dømtes bevægelses- og opholdsfrihed ud over i den eller de konkrete kommuner eller de byer eller de bydele, som opfattes af opholdsforbuddet, og derved muligheden for i $\varnothing$ vrigt at opretholde et almindeligt liv." ${ }^{\prime 85}$
\end{abstract}

Dette har mere karakter af en klassisk proportionalitetsvurdering, som den ifølge litteratur og praksis bør gribes an.

En anden særlig (mellem)variant af proportionalitetsproblematikken opstår i de relativt mange situationer, hvor det relevante ministerium ikke som sådan selv foretager en generel proportionalitetsvurdering, men $\mathrm{i}$ stedet henskyder denne til de retsanvendende myndigheder. Et eksempel herpå er fx Justitsministeriets argumentation i bemærkninger til lovforslag nr. L 193 af 26. april 2017 om forbud mod anvendelse af bestemte ejendomme som samlingssted for en gruppe (et af lovforslagene i den politiske aftale om en ny rocker- og bandepakke). ${ }^{86} \mathrm{Her}$ er det en ret central del af ministeriets mere overordnede proportionalitetsvurdering, at

\footnotetext{
85 Lovforslagets almindelige bemærkninger, s. 8.

${ }^{86}$ Lovforslag nr. L 193, Folketinget 2016-17.
} 
de retshåndhævende myndigheder i den konkrete situation kan udøve et ret stort skøn og i den forbindelse kan tænke proportionalitetsafvejningen ind. ${ }^{87}$

\footnotetext{
"Endelig lægger udvalget vægt på, at nedlæggelse af samlingsstedforbud forudsætter, at kommunen foretager en konkret vurdering i det enkelte tilfælde af, om forbuddet er proportionalt, og i den forbindelse en afvejning af på den ene side interessen $i$ at sikre en vidtgående forsamlingsfrihed for lovlige foreninger mv. og på den anden side de modstående hensyn til at imødegå den ulempe og utryghed for de omkringboende, som anvendelsen af ejendommen som samlingssted for gruppen i det konkrete tilfælde indebærer. Et samlingsstedsforbud vil således ikke kunne nedlægges i situationer, hvor dette ikke vil foreneligt med grundlovens $\S 79$ og artikel 11 i Den Europæiske Menneskerettighedskonvention."
}

Denne tankegang ses også afspejlet i udtalelser som denne: "Der er endvidere lagt vægt på, at kriminalforsorgen skal undlade at træffe afgørelse efter de foreslåede bestemmelser, hvis ganske særlige grunde gør sig gældende (§ $3 \mathrm{nr} .1$ ), eller foranstaltningen er åbenbar unødvendig $(\S 3, \mathrm{nr} .2,5$ og 8)" 88

Strategien med at uddelegere proportionalitetsvurderingen til forvaltningsmyndighedernes konkrete udmøntning er altså en meget typisk foreteelse i ministeriernes argumentation for nye lovbestemmelsers overensstemmelse med international ret.

\subsection{Skønspræget retsgrundlag}

Et andet signifikant træk ved en stor del af den analyserede lovgivning er, at retsgrundlaget har en meget skønspræget karakter og derfor ikke giver megen vejledning til retsanvenderne. Det er den tidligere fremhævede lov om et tildækningsforbud ${ }^{89}$ et illustrativt eksempel på. Her lyder den centrale bestemmelse som følger:

$\S 134$ c. Den, som på offentligt sted bærer en beklædningsgenstand, der skjuler vedkommendes ansigt, straffes med bøde.

Stk. 2. Det i stk. 1 nævnte forbud gælder ikke for tildækning af ansigtet, der tjener et anerkendelsesværdigt formål.

Det burde være ret tydeligt, at ordlyden giver grundlag for et meget vidt skøn, og at der, selv om der er tale om en potentielt set meget indgribende regulering af den personlige frihed og religionsfriheden, ikke gives nærmere vejledning i den konkrete formulering af paragraffen. Hvornår tildækning 'tjener et anerkendelsesværdigt formål' og dermed alligevel er lovligt, er jo ret afgørende for forståelsen af den nye lov. I høringssvaret til lovforslaget anbefaler Institut for Menneskerettigheder da også meget eksplicit, at de skønsmæssige formuleringer udfoldes og specificeres, idet man fx anfører, at ministeriet bl.a. bør præcisere, i hvilke tilfælde tildækning af ansigtet i sig selv kan anses som en meningstilkendegivelse, hvordan tildækningsforbuddet skal administreres på institutioner uden en skarp overgang mellem det offentlige og det private rum, og efter

\footnotetext{
${ }^{87}$ Dette ræsonnement er i $\varnothing v r i g t$ inspireret og baseret på en særlig betænkning nr. 1526/2016 afgivet af Udvalget om indsatsen over for rockerborge, hvilket forklarer referencen til "udvalget" i citatet.

88 Jf. bemærkningerne til lovforslag nr. L 190 af 26. april 2017 om ændring af straffeloven, lov om forbud mod ophold i bestemte ejendomme og lov om fuldbyrdelse af straf $\mathrm{mv}$.

${ }^{89}$ Lovforslag nr. L 219 af 11. april 2018 om ændring af straffeloven
} 
hvilke omstændigheder politiet vil kunne håndhæve tildækningsforbuddet med henblik på at sikre, at det i praksis ikke håndhæves diskriminerende ${ }^{90}$.

Et andet eksempel er lovforslaget af 17. december 2014 om ændring af lov om pas til danske statsborgere m.v., udlændingeloven og retsplejeloven, som var et led i en styrket indsats mod rekruttering til væbnede konflikter i udlandet, og som blandt andet giver mulighed for udrejseforbud og inddragelse af pas ved mistanke om afrejse til fx Syrien for at kæmpe med IS. Her lyder den centrale bestemmelse, at passet kan inddrages, "når der er grund til at antage, at den pågældende har til hensigt i udlandet at deltage i aktiviteter, hvor dette kan indebære eller forøge en fare for statens sikkerhed, andre staters sikkerhed eller en væsentlig trussel mod den offentlige orden" ${ }^{\prime 1}$

Denne regulering må også betegnes som yderst skønspræget i betragtning af, at den handler om indgreb i nogle ret grundlæggende rettigheder om forsamlingsfrihed og personlig frihed. Også her opfordrer IMR til en række præciseringer, inden lovforslaget endeligt vedtages. ${ }^{92} \mathrm{I}$ relation til den citerede bestemmelse anbefaler instituttet, at man med henblik på at fremme den enkeltes menneskerettigheder "præciserer rækkevidden (...) i bemærkningerne til lovforslaget, herunder med særligt fokus på personer, der ikke deltager aktivt $i$ kamphandlinger". IMR anbefaler også, at man med henblik på at sikre, at krænkelse af menneskeretten undgås, skærper kravet i bestemmelsen, "for eksempel således at der skal være konkrete grunde til at antage, at en person vil deltage eller har deltaget i de næunte aktiviteter."

Et sidste meget illustrativt eksempel er lovforslaget ${ }^{93}$, der blev udarbejdet i kølvandet på et betænkningsarbejde af det såkaldte "Rockerborgsudvalg" ${ }^{94}$, som havde til opgave at kortlægge de praktiske problemer med rockerborge og komme med forslag til en styrket indsats. Her lyder den centrale bestemmelse i lovforslaget som følger:

$\S$ 1. Kommunalbestyrelsen kan nedlægge forbud mod, at en ejendom anvendes som samlingssted for en bestemt gruppe, hvis gruppens anvendelse af ejendommen som samlingssted er egnet til at medføre væsentlig ulempe og utryghed for de omkringboende, jf. dog stk. 2.

Stk. 2. Vil et forbud i medfør af stk. 1 være uforholdsmæssigt indgribende uden forudgående advarsel, skal kommunalbestyrelsen først meddele advarsel om, at forbud kan forventes nedlagt, hvis gruppens anvendelse af ejendommen som samlingssted fortsætter med at være egnet til at medføre væsentlig ulempe og utryghed for de omkringboende, jf. dog stk. 3. En advarsel gælder i 2 år.

Her kan man ikke i lovteksten se nogen nærmere angivelse af, hvilken slags gruppe der skal være tale om, hvornår noget kan siges at udgøre et samlingssted, og ikke mindst hvilken type ulempe og utryghed for naboerne, der skal være tale om. I forlængelse heraf er det en central anbefaling i IMR's høringssvar, at Justitsministeriet "sørger for, at de centrale kriterier, som kommunerne skal lægge til grund i sit skøn af, om et forbud skal udstedes, fremgår direkte af lovteksten." 95

\footnotetext{
90 SE IMR's høringssvar af 6. marts 2018.

${ }^{91}$ Lovforslag nr. L 99, Folketinget 2014-15.

92 IMR's høringssvar af 6. december 2014.

${ }^{93}$ Lovforslag nr. L 193 af 26. april 2017 om forbud mod anvendelse af bestemte ejendomme som samlingssted for en gruppe.

${ }^{94}$ Betænkning $\mathrm{nr}$. 1562/2016 om indsatsen over for rockerborge mv.

95 Jf. IMR's høringssvar af 10. februar 2017 om Betænkning nr. 1562/2016 om indsatsen over for rockerborge mv. Bemærk, at
} 
Det bemærkelsesværdige er, at en række af de efterspurgte kriterier for så vidt fremgår af det fremsatte lovforslag, blot ikke af selve lovteksten, men af de ledsagende såkaldte lovbemærkninger, og dette synes at være et mere generelt træk.

\subsection{Regulering via lovbemærkninger}

Det er således i ganske vidt omfang sådan, at de ovenfor gennemgåede vagt og skønsmæssigt formulerede lovbestemmelser, på mere konkret vis specificeres og præciseres i forarbejderne til lovgivningen, typisk i lovbemærkningerne. For det netop nævnte eksempel om kommunernes udvidede beføjelser til at gribe ind over for såkaldte rockerborge gælder således, at der i bemærkningerne til § $1^{96}$ er en uddybende definition på, hvad der skal forstås ved en "gruppe", hvornår noget kan karakteriseres som et "samlingssted", og under hvilke nærmere omstændigheder noget kan siges at være til "væsentlig ulempe og tryghed".

I relation til det sidstnævnte anføres det for eksempel:

"Med "væsentlig ulempe og utryghed" sigtes til gener, der er så alvorlige og normalt længerevarende, at de vil kunne sidestilles med de gener, der kan opleves, når der i tilknytning til en ejendom foregår virksomhed på en måde, som systematisk indebærer strafbare handlinger - f.eks. systematisk hashhandel og som er egnet til at medføre væsentlig ulempe og utryghed hos de omkringboende.

Om dette er tilfældet vil bero på en samlet konkret vurdering. I vurderingen vil det bl.a. kunne indgå, om anvendelsen af ejendommen som samlingssted for gruppen fører til hyppige støjgener eller hyppige trafikale gener. Det vil endvidere kunne indgå, om personer, der færdes på ejendommen, begår strafbare forhold på eller i området omkring ejendommen eller udviser chikanøs eller truende adfærd i området. Herudover vil det kunne indgå, om anvendelsen af ejendommen som samlingssted for gruppen giver anledning til angreb eller konkret risiko for angreb rettet mod ejendommen eller personer, der opholder sig på ejendommen. Der er ikke tale om en udtømmende opregning af mulige ulempe- og utryghedsskabende gener.

Generne vil for at kunne danne grundlag for et forbud skulle gå klart ud over, hvad der kan forventes i det pågældende område.

Konstatering af blot én af de ovennævnte gener vil som udgangspunkt ikke alene kunne begrunde et forbud. Der vil normalt skulle konstateres en flerhed af gener over en længere periode. Der vil dog kunne være tilfælde, hvor kun én bestemt type af gener forekommer over en længere periode eller med en sådan hyppighed eller intensitet, at dette i sig selv vil være tilstrækkeligt til at begrunde et forbud."”7

Det kan undre, at disse formuleringer ikke er blevet inkluderet i lovteksten, for der er tale om helt centrale præciseringer af mere generel karakter. Og lovbemærkningerne stopper endda ikke her, for efterfølgende kommer en uddybende forklaring og eksemplificering på, hvilken type støjgener, trafikale gener, strafbare forhold, chikanøs eller truende adfærd mv., der kan lægges vægt på i kommunens vurdering af, om et opholdsforbud kan komme på tale.

Alt i alt giver lovteksten ved en umiddelbar læsning kommunerne et indtryk af, at der er vide rammer og en relativt nem adgang til at udstede opholdsforbud, for gruppens brug af ejendommen skal blot være "egnet til at medføre væsentlig ulempe og utryghed for de omkringboende", hvilket selve eksistensen af en rockerborg for så vidt kan argumenteres for at være. Man skal altså et godt stykke ned i lovbemærkningerne, før

\footnotetext{
${ }^{96}$ Se lovforslag som fremsat (L 193, Folketinget 2016-17), s. $30 \mathrm{ff}$.

97 Ibid.
} 
man finder ud af, at dette langt fra er tilstrækkeligt, og at der skal ganske meget mere til, før et forbud lovligt kan udstedes.

Lignende mønstre kan identificeres i en række andre lovforslag. Særligt lovforslaget om skærpelse af forholdene for udlændinge på tålt ophold (afviste asylansøgere og udvisningsdømte, der på grund af forholdene i deres hjemland ikke kan hjemsendes) kan fremhæves i den forbindelse. Her bliver blandt andet indført en adgang til at pålægge udlændinge underretningspligt, hvis de overnatter uden for indkvarteringsstedet og en skærpet straf for overtrædelse heraf. Den centrale lovbestemmelse ${ }^{98}$ anfører, at

\footnotetext{
"Udlændingestyrelsen bestemmer, medmindre særlige grunde taler derimod, at en udlænding, som er pålagt at tage ophold på et bestemt indkvarteringssted, jf. stk. 8, 1. pkt., skal give underretning til indkvarteringsoperatøren, hvis udlændingen i tidsrummet mellem kl. 23.00 og 6.00 opholder sig uden for indkvarteringsstedet." (min fremhævning)
}

Den nye underretningspligt beskrives i de almindelige bemærkninger i absolutte vendinger, altså som en ny undtagelsesfri pligt for de omfattede udlændinge på tålt ophold og kriminelle udviste. Der henvises i den forbindelse til en politisk aftale, som (mindretals-)regeringen har indgået med tre andre politiske partier, og som havde det som et centralt element at indføre en sådan underretningspligt som led i en generelt strengere kontrol over for udlændinge. ${ }^{99}$ Det er således først i de specielle bemærkninger til bestemmelsen (helt henne på side 55 i det samlede lovforslag med bemærkninger) at det fremgår, at afgørelse om underretningspligt ikke er obligatorisk, og først her man uddyber lovbestemmelsens forbehold "medmindre særlige grunde taler derimod". Ministeriet skriver herom:

\footnotetext{
"Udlændingestyrelsen vil derfor alene kunne undlade at træffe afgørelse om underretningspligt, hvis særlige grunde taler derimod. Dette omfatter navnlig tilfælde, hvor det i det konkrete tilfælde må anses at være helt ubetænkeligt at undlade at træffe afgørelse om underretningspligt, f.eks. fordi udlændingen gennem en længere periode har overholdt alle forpligtelser, og der derfor ikke er helt samme behov for at opretholde en underretningspligt. Det vil også være tilfældet, hvis det vil være uforeneligt med Danmarks internationale forpligtelser at pålægge en udlænding at give underretning til indkvarteringsoperatøren, jf. herved de almindelige bemærkninger, afsnit 12. Hvis f.eks. en udlænding har efterlevet myndighedernes påbud om opholds-, melde- og underretningspligt i en sådan periode, jf. Højesterets dom af 1. juni 2012 (UfR. 2012.2874 H), at opretholdelse heraf i det konkrete tilfælde må anses for et indgreb i den pågældendes bevægelsesfrihed i strid med f.eks. Den Europæiske Menneskerettighedskonventions artikel 2 i 4. tillægsprotokol, vil sådanne kontrolforanstaltninger ikke kunne pålægges."
}

Heraf fremgår det altså, at man slet ikke kan træffe afgørelse om underretningspligt ved overnatning andre steder, hvis der ikke har været problemer med den pågældende udlændings overholdelse af sine hidtidige forpligtelser. Og at det også efter omstændighederne kan være i strid med Danmarks internationale forpligtelser i medfør af EMRK at pålægge en sådan underretningspligt, hvilket en dansk Højesteretsdom har fastslået i en konkret situation på grundlag af de tidligere (lempeligere) regler. I det angivne afsnit 12 i de almindelige bemærkninger, der indeholder Justitsministeriets redegørelse for forholdet til Danmarks internationale forpligtelser, får man imidlertid ikke megen yderligere vejledning. I det centrale afsnit herom anføres følgende:

\footnotetext{
98 Udlændingelovens $§ 42$ a, stk. 10

${ }^{99}$ Se de almindelige bemærkninger, s. 10
} 
"Reglerne om opholds-, melde- og underretningspligt skal i øvrigt administreres i overensstemmelse med Danmarks internationale forpligtelser, jf. Højesterets dom af 1. juni 2012 (UfR 2012.2874 H). Det indebærer bl.a., at Udlændingestyrelsen og politiet løbende skal vurdere, om påbud om opholds-, melde- og underretningspligt er i overensstemmelse med Danmarks internationale forpligtelser. I den konkrete sag fandt $\mathrm{H} \varnothing$ jesteret efter en samlet vurdering, at Udlændingeservices (nu Udlændingestyrelsen) afgørelse om, at den pågældende udlænding skulle bo og overnatte i Center Sandholm, udgjorde et uproportionalt indgreb i hans bevægelsesfrihed i strid med artikel 2 i Tillægsprotokol 4 til Den Europæiske Menneskerettighedskonvention. Afgørelsen måtte derfor ophæves som ugyldig.

Det er på denne baggrund Udlændinge-, Integrations- og Boligministeriets opfattelse, at underretningspligten ikke er mere indgribende end nødvendigt og derfor er i overensstemmelse med EMRK." 100

Disse bemærkninger er delvist selvmodsigende og kan ikke siges at være afklarende og vejledende for retsanvenderne. Der redegøres fx ikke nærmere for, hvorfor Højesteret i den konkrete sag kom frem til, at myndighedernes krav om opholds- og overnatningspligt var uproportionalt og derfor i strid med EMRK, altså hvilke faktiske omstændigheder der blev lagt vægt på i dommen, og som de administrerende myndigheder derfor skal lægge sig på sinde, hvis de vil undgå at bryde med Danmarks konventionsmæssige forpligtelser. Det forekommer også paradoksalt, at det sporadiske referat af dommen efterfølges af ministeriets overordnede konklusion om, at den nye lov er proportional og konventionsmæssig, når den indebærer en skærpelse af forholdene for udlændinge på tålt ophold og dermed logisk set må indebære en forhøjet risiko for konventionsstridig praksis.

\subsection{Begrænset vejledning til retsanvenderne}

Det er i det hele taget en generel tendens i de analyserede lovforslag, at retsanvenderne kun får begrænset vejledning i, hvilken betydning internationale forpligtelser har for den konkrete forståelse af og udmøntning lovgivningen. Dette gælder også i sager, der indebærer meget voldsomme indgreb over for borgerne.

Ud over det tidligere nævnte lovforslag om en styrket indsats mod rekruttering til væbnede konflikter i udlandet ${ }^{101}$, er problemstillingen fx på spil i lovforslaget om kriminalisering af udtrykkelig billigelse af visse strafbare handlinger som led i religiøs oplæring ${ }^{102}$. Lovforslaget fik blandt andet følgende bemærkning med på vejen af Institut for Menneskerettigheder: "Instituttet finder, at bestemmelsens anvendelsesområde er særdeles vagt og uklart, og derfor medfører risiko for retsusikkerhed. Instituttet vurderer således, at det i praksis vil være meget svært at afgøre, hvornår en ytring konkret vil være omfattet af bestemmelsen." ${ }^{103}$ Kritikken fremstår næsten endnu mere tydeligt i forbindelse med høringen over et andet lovforslag, nemlig lovforslaget om opholdsforbud for dømte for rocker- og bandekriminalitet" ${ }^{104}$ Her anbefaler IMR, "at det fremgår af den foreslåede bestemmelse om opholdsforbud, at der skal foretages en proportionalitetsvurdering, og at det tydeliggøres i bemærkningerne til loven, hvilke kriterier der skal indgå i denne afvejning." 105

\footnotetext{
100 Lovforslag nr. L 51, Folketinget 2016-17, de almindelige bemærkninger, afsnit 12 (s. 47-48).

${ }^{101}$ L 99 af 17. december 2014, se s. 14

102 L 18 af 5. oktober 2016

103 IMR's høringssvar af 11. juli 2016.

104 Lovforlag nr. 190, Folketinget 2016-17.

105 IMR's høringssvar af 7. september 2017.
} 
Alt i alt angives det som en typisk mangel, at der ikke gives bedre anvisninger til de myndigheder, der skal tage de nye lovbestemmelser $\mathrm{i}$ anvendelse, således at lovgivningsmagten sikrer sig, at der administreres inden for rammerne af Danmarks internationale forpligtelser.

Et andet supplerende forhold er, at det virker som om, at de mangelfulde retningslinjer altid fortolkes til menneskerettighedernes ulempe, ikke til deres fordel. Eller sagt på anden vis: Der er ofte tale om relativt vidtgående bestemmelser, som imidlertid ved nærmere eftersyn skal fortolkes mere restriktivt for at undgå konflikt med internationale konventionsforpligtelser. Derfor ses der også eksempler på, at i den lovforberedende fase efterlyses mere tydelige rammer og retningslinjer, der tydeligg $\varnothing r$ de menneskeretlige problemer og barrierer for de retsanvendende myndigheder. Et godt eksempel herpå er anbefalingen fra IMR i forbindelse med lovforslag ${ }^{106}$ om ændring af udlændingeloven i kølvandet på flygtningekrisen.

\footnotetext{
"Instituttet anbefaler derfor, at der i loven indsættes klare regler om den maksimale tidsmæssige udstrækning både af frihedsberøvelse ved indrejse og af suspensionen af den enkelte udlændinges ret til domstolskontrol, således at loven begrænser regeringens beføjelser i overensstemmelse med Danmarks internationale forpligtelser.

Institut for Menneskerettigheder har desuden en række anbefalinger, der alle har til formål at bidrage til at skabe større sikkerhed for, at myndighederne og domstolene holder sig inden for grænserne af Danmarks internationale forpligtelser. Anbefalingerne sammenfattes i det følgende og fremgår også under høringssvarets enkelte afsnit." ${ }^{107}$
}

Herefter kommer instituttet med en række mere konkrete anbefalinger, $f x$ at der fastsættes en $\varnothing v r e$ grænse på fx 7 eller 14 dage for frihedsberøvelsens varighed, at suspension af domstolsprøvelse i almindelighed kun kan ske i 14 dage ad gangen, og at det præciseres, at der skal foretages en konkret og individuel proportionalitetsvurdering af indgrebet i bevægelsesfriheden løbende og mindst hver 6. måned. Det er således det klare budskab, at det vage og skønsmæssige retsgrundlag ikke i tilstrækkeligt grad gør de menneskeretlige krav tydelige for retsanvenderne, og at der derfor efter instituttets opfattelse er behov for at opstille klare regler i selve loven, hvis der skal opnås tilstrækkelig sikkerhed for, at man med loven holder sig inden for de internationale konventioner.

Bekymringen for, om de konventionsmæssige implikationer er tilstrækkeligt ekspliciteret for retsanvenderne, er som allerede nævnt et gennemgående træk. Og meget tyder på, at det for Institut for Menneskerettigheder ses som et mere generelt problem ved deres lovsikrede opgave med at sikre, at Danmark overholder internationale menneskeretlige forpligtelser. Således fremhæver IMR i forbindelse med deres høringssvar vedrørende skærpede regler ${ }^{108}$ om udvisning af kriminelle udlændinge blandt andet, at man "i flere omgange har peget på behovet for, at Den Europæiske Menneskerettighedsdomstols (EMD) praksis tydeliggøres (...) og gøres lettere tilgængelig for praktikere", samt "at informationsmateriale løbende opdateres efterhånden som praksis udvikler sig. Det anbefales også, at "der i lovforslaget og retningslinjerne inkluderes yderligere praksis dels fra før årtusindeskiftet, dels - og navnlig - alle domme, hvor EMD har fundet udvisning i strid med EMRK." 109

\footnotetext{
106 Lovforslag L 62, Folketinget 2015-16.

107 IMR's høringssvar af 19. november 2015.

108 Lovforslag L 156, Folketinget 2017-18.

109 IMR's høringssvar af 9. februar 2018.
} 
Her adresserer IMR altså et mere generelt problem, nemlig at de retsanvendende myndigheder ikke i tilstrækkeligt omfang har mulighed for at orientere sig i relevant EMD-praksis, og at ministeriet heller ikke i det konkrete lovforslag med tilhørende bemærkninger i tilstrækkelig grad har redegjort for domme, hvor udvisning blev erklæret for konventionsstridig.

Dette er en bemærkelsesværdig kritik og skal tilmed ses i lyset af, at retsanvenderne i den konkrete situation var domstolene, da det handlede om skærpede regler for udvisning. I forhold til andre administrerende myndigheder, som fx kommuner og styrelser, må domstolene trods alt antages at være bedre klædt på til selv at håndtere internationale normer og fremfinde relevant domspraksis. Så i alle de situationer, hvor den nye lovgivning implementeres af forvaltningen, er problemet med mangelfuld vejledning af retsanvenderne så meget desto større.

\section{6. Nuancering - en mere eksemplarisk inddragelse på særlige områder?}

Da jeg foretog en ekstra gennemgang af relevante lovforslag fra Folketingets dokumentsamling, jf. indledningen, dukkede to tilfældegrupper frem, der begge kunne siges at foretage en lidt mere eksemplarisk inddragelse af international ret i lovforslagets bemærkninger, end de ovenstående analyseresultater ellers dokumenterede.

For det første synes der at være en større opmærksomhed om international rets betydning i visse lovforslag vedrørende grænseregulering og regulering af tilgangen af flygtninge. Dette kommer fx til udtryk i bemærkningerne til L 72 fra efteråret 2014 om midlertidig beskyttelsesstatus for visse udlændinge samt afvisning af realitetsbehandling af asylansøgninger, når ansøgeren har opnået beskyttelse i et andet EU-land mv ${ }^{110}$. Her foretages en mere gennemgående inddragelse af lovforslagets forhold til både EMRK, FN's Flygtningekonventionen og relevante EU-retlige forpligtelser, ligesom relevant praksis fra Den Europæiske Menneskerettighedsdomstol og fra Flygtningenævnet ${ }^{111}$ refereres. Samme indtryk giver to af de lovforslag fra foråret 2017, der var en reaktion på den såkaldte 'flygtningekrise', nemlig L 153 om mulighed for i en krisesituation at afvise asylansøgere ved grænsen og L 154 om skærpelse af reglerne om tidsubegrænset opholdstilladelse ${ }^{112}$. Her inddrages både Dublinforordningen, EU-retlige forpligtelser og EMRK. ${ }^{113}$

Det er svært at drage entydige konklusioner om, hvad den mere omfattende inddragelse på dette område kan skyldes. Måske er det blot et udtryk for, at der simpelthen er flere åbenlyse og tungtvejende internationale retskilder at tage højde for. Det kan også hænge sammen med, at initiativerne i både den nationale og international presse har været genstand for megen kritik og debat. Eller det kan tænkes at hænge sammen med det forhold, at der ikke er adgang til egentlig domstolsprøvelse i flygtningesager, hvorfor lovgivningsmagten må forventes at gøre sig ekstra umage. En nærmere afdækning af årsagerne falder imidlertid uden for, hvad der rummes inden for omfanget af denne artikel.

\footnotetext{
110 Lovforslag L 72, Folketinget 2014-15, 1. samling.

${ }^{111}$ Flygtningenævnet er et domstolslignende nævn, der fungerer som øverste klageinstans for sager om asyl og udlændingeret. På grund af en endelighedsbestemmelse i udlændingeloven kan sådanne sager ikke undergives egentlig pr $\varnothing$ velse ved domstolene.

112 L 153, Folketinget 2017-18 og L 154, Folketinget 2017-18.

113 Man kunne også overveje at nævne L 197, Folketinget 2017-18, som en illustration af tendensen. Dog er dette lovforslag i vid udstrækning en mindre revision af og forlængelse af de allerede foretagne ændringer i udlændingeloven $\mathrm{i}$ anledning af flygtningekrisen.
} 
For det andet kan der måske spores en tendens til en mere grundig inddragelse af internationale menneskerettigheder i lovforslag, der handler om social- og sundhedsmæssige forhold. I hvert fald forekommer der to eksempler herpå, nemlig L 121 fra foråret $2016^{114}$ om mulighed for anvendelse af personlige alarm- og pejlesystemer på sygehuse, tilbageholdelse af patienter mv. og L 185 fra foråret $2017^{115}$ om anvendelse af tvang ved somatisk behandling af varigt inhabile. Det er karakteristisk for begge disse lovforslag, at de ikke blot behandler forholdet til EMRK, men også FN's handicapkonvention (og for sidstnævnte lovforslags vedkommende tillige konvention om menneskerettigheder og biomedicin). Der er altså ikke tale om en snæver relevansvurdering.

De to lovforslag på social- og sundhedsområdet byder også på en noget mere udførlig proportionalitetsvurdering, og det konkrete krav om en balance i retsanvendelsen er i højere grad skrevet ind i selve lovteksten. Således fremgår det $\mathrm{fx}$ af den nye bestemmelse i sundhedslovens $\S 27 \mathrm{~b}$, at "Ethvert indgreb efter dette kapitel skal være så skånsomt og kortvarigt som muligt og stå i rimeligt forhold til formålet med indgrebet. Det mindst indgribende indgreb skal anvendes, hvis det er tilstrækkeligt til at opnå formålet. Alle indgreb skal udføres med størst mulig hensyntagen til den pågældende patient for at undgå unødige krænkelser og ulempe" ${ }^{\prime 116}$. Denne fremgangsmåde står i ret tydelig kontrast til den tidligere fremhævede tendens til at nøjes med en tilføjelse i lovbemærkningerne om, at "den foreslåede bestemmelse forudsættes administreret i overensstemmelse med Danmarks internationale forpligtelser".

Heller ikke for disse to lovforslags vedkommende, kan der udledes noget sikkert om årsagerne til en mere udførlig inddragelse af international ret. Det synes oplagt at gætte på forskelle i administrationskultur på forskellige ministeriers ressortområder, ligesom social- og sundhedsområdet ej heller er lige så politisk kontroversielt som fx spørgsmål om udlændinge, integration og terror, hvorfor menneskerettighedshensyn kan opfattes som mere legitime. En nærmere analyse af sådanne variationer i materialet kunne være interessant at foretage i fremtidige studier.

\subsection{Opsummering - hvordan forvalter lovgivningsmagten deres ansvar?}

Den foretagne analyse af lovforslagene og deres inddragelse af internationale konventioner giver anledning til en række konklusioner.

For det første er det bemærkelsesværdigt, at det som altovervejende udgangspunkt kun er EMRK, der inddrages og behandles i lovforslaget med tilhørende bemærkninger. Dette gælder også i situationer, hvor der er andre internationale normer, som er relevante for det lovforslagets genstandsfelt, og det er vel at mærke tilfældet, selv om alle konventionerne udg ør en retlig forpligtelse for lovgiver. Det er således en forpligtelse, lovgiver ikke eksplicit forholder sig til.

Det er også interessant set i lyset af diskussionerne om inkorporering, hvor det ofte er fremført som et argument for at afholde sig fra inkorporering af yderligere konventionsforpligtelser, at "de jo allerede er en del af gældende ret". Når det i andre sammenhænge er blevet fremhævet, at domstolene og de administrative myndigheder kun meget sjældent inddrager andre internationale konventioner end EMRK, gælder dette altså

\footnotetext{
${ }^{114}$ L 121, Folketinget 2015-16.

${ }^{115}$ L 185, Folketinget 2016-17.

${ }^{116}$ Se L 121, Folketinget 2015-16, s. 1 og de specielle bemærkninger på s. 16.
} 
i udpræget grad også lovgivningsmagten. Ud fra et praktisk perspektiv har det således en afgørende betydning, om konventioner er inkorporeret eller ej i den forstand, at ikke-inkorporerede konventioner spiller en langt svagere rolle, om nogen overhovedet.

Lovgivningsmagtens anvendelse af international ret synes også at være også nølende i en anden forstand, idet man kun synes at forholde sig til de konventionsmæssige konsekvenser af lovforslagenes hovedindhold, mens de mere sekundære lovelementer ikke nødvendigvis vurderes i forhold til relevant international ret. Der anvendes med andre ord en minimalistisk tilgang til opgaven med at vurdere lovforslagenes forhold til Danmarks konventionsmæssige forpligtelser.

Vendes opmærksomheden herefter mod den inddragelse af international ret, der foretages i lovforslagene, og som altså i næsten alle situationer er en vurdering af forholdet til Den Europæiske Menneskerettighedskonvention, træder også her interessante forhold frem. Det er som bekendt et generelt krav for de fleste materielle bestemmelser $\mathrm{i}$ konventionen, at indgreb i konventionens rettigheder kun kan foretages, hvis det er nødvendigt i et demokratisk samfund, dvs. er proportionalt.

Her viser analyserne af de seneste års lovforslag, at denne påkrævede proportionalitetsvurdering som udgangspunkt kun foretages på et meget overordnet plan i forbindelse med fremsættelse og vedtagelse af lovforslaget og somme tider har en nærmest postulerende karakter. Ræsonnementet for denne fremgangsmåde er som oftest den, at det er på det retsanvendende niveau, at proportionalitetsafvejningen bør foretages, men lovteksten opstiller sjældent nogle nærmere retningslinjer herfor eller fremhæver de kriterier, som proportionalitetsvurderingen $b \varnothing r$ hvile på i de konkrete situationer. Vejledningen har mange gange karakter af en form for besværgelse, hvor lovgivningsmagten fremhæver, at de nye regler naturligvis skal administreres i overensstemmelse med Danmarks internationale forpligtelser.

I forlængelse heraf er det et gennemgående karakteristikum, at lovgrundlaget er meget skønspræget formuleret, mens de mere præcise udlægninger af teksten og konkrete anvisninger til de retsanvendende myndigheder i meget vidt omfang findes i lovbemærkningerne. Ikke sjældent giver lovteksten efter sin umiddelbare ordlyd grundlag for en relativt indgribende retstilstand, der ved en nærlæsning af lovbemærkningerne skal blødes op, hvis de konventionsmæssige forpligtelser skal overholdes. Dette efterlader retsanvenderne i en vanskelig situation, for lovgivningsmagten har på den ene side lagt ansvaret for at undgå konventionsbrud på deres skuldre, men samtidigt har regeringen ikke givet de retsanvendende myndigheder særlig gode muligheder for at leve op til dette ansvar, fordi den mere konkrete vejledning om relevante konventionsmæssige forpligtelser i den konkrete sag forudsætter, at myndighederne selv nærstuderer lovbemærkninger og evt. foretager en selvstændig fortolkning af relevant EMD-praksis. Det kan måske forventes af domstolene, men man kan stille sig spørgsmålet, hvor realistisk forventningen er i relation til de umiddelbare administrative myndigheder, som fx en kommunerne eller politiet.

Disse analyseresultater står i ganske vidt omfang i modsætning til de præmisser, hvorpå Danmarks hidtidige implementering af internationale retsnormer hviler. For som tidligere beskrevet har man i vidt omfang undladt at inkorporere menneskerettighedskonventioner og pålagt domstolene at praktisere en tilbageholdende selvstændig fortolkning af international ret med udtrykkelig henvisning til, at ansvaret for at implementere de internationale forpligtelser og justere lovgivningen i lyset heraf bedst varetages af den demokratisk legitime lovgivningsmagt. Nu viser det sig imidlertid, at lovgivningsmagten kun i begrænset omfang lever op til dette ansvar, idet man oftest foretager en minimalistisk vurdering af forholdet til internationale konventioner 
og i ganske vidt omfang lader de retsanvendende myndigheder stå tilbage med den ofte komplekse opgave at vurdere og sikre overensstemmelse med konventionerne.

Det kan ikke afvises, at afgrænsningen og udvælgelsen af materialet har betydet, at analysen har haft særligt fokus på de lovforslag, hvor der har været en særlig risiko for problemer med overholdelse af internationale forpligtelser, jf. de metodiske bemærkninger ovenfor. En ekstra gennemgang af det samlede søgemateriale viste da også, at der på enkelte områder har fundet en mere eksemplarisk inddragelse af international ret sted. Dette ændrer dog ikke ved, at analysens resultater er bemærkelsesværdige. For det er jo netop i de problemfyldte farvande, at internationale menneskerettighedskonventioner for alvor har deres berettigelse og skal vise deres værd som reel barriere for de nationale magthavere.

\section{På hvilken måde gælder menneskerettighederne i Danmark?}

Analysens resultater efterlader os med det relativt grundlæggende spørgsmål, på hvilken måde international ret egentlig gælder i Danmark. De analyserede lovforarbejder giver både vigtige bidrag til en forståelse af, hvordan regeringen i praksis inddrager internationale menneskerettighedsforpligtelser i lovgivningsprocessen, men resultaterne har også konsekvenser for, hvordan vi mere generelt kan beskrive den internationale rets betydning i dansk ret.

I fraværet af udtrykkelig regulering af forholdet mellem national og international ret på forfatningsniveau og lovniveau, har man i vidt omfang lænet sig op af synspunkterne i juridisk teori, og i de forskellige sagkyndige betænkninger, når betydningen af international ret skal beskrives. Retspraksis har været spredt og ikke for alvor bidraget til et konsistent billede af retstilstanden.

Således har det klare formelle udgangspunkt, som doceres i officielle juridiske og politiske sammenhænge, været, at vi i Danmark har et dualistisk system, hvor international ret ikke uden videre er en del af det nationale normsystem. Videre betones det, at der i praksis gælder en række forskellige fortolkningsprincipper, således at internationale konventioner er en del af gældende ret og også anvendes som sådan i det praktiske retsliv, hvorfor en egentlig inkorporering for at opnå effektiv implementering, ikke er påkrævet. Samtidigt har man i en række (inkorporerings-)betænkninger understreget betydningen af, at domstolene fortsætter sin tilbageholdende fortolkningstradition i sager om konventionsforpligtelser, først og fremmest med henvisning til risikoen for forskydning af magt fra lovgivningsmagt til domstole.

Understregningen af domstolenes tilbageholdende fortolkning hviler imidlertid på en forventning om, at lovgivningsmagten løbende afklarer tvivlsomme fortolkningsspørgsmål, men denne grundlæggende forfatningsmæssige præmis bliver langt fra bekræftet af den foretagne analyse. Tværtimod kan det konkluderes, at regeringen i det lovforberedende arbejde ikke foretager en meget udførlig redegørelse for og vurdering af forholdet til international ret og i nogle tilfælde endog anvender en lovgivningsteknik, hvor lovteksten giver et mere firkantet og restriktivt billede af retstilstanden, end de konventionsmæssige forpligtelser ved nærmere eftersyn tillader.

Ud fra et mere overordnet perspektiv kan dette give anledning til at stille spørgsmålet, i hvilket omfang menneskerettighederne overhovedet gælder i Danmark? Der synes i hvert fald at tegne sig et klart billede af, at der kun foretages en meget nødtvungen og overfladisk inddragelse i de situationer, hvor konventionerne kan 
være ubelejlige, altså når de for en umiddelbar betragtning kan være på kant med stærke ønsker fra regering og Folketing. Her inddrages kun de mest åbenbare konventionsforpligtelser, typisk den inkorporerede EMRK, og man forsømmer ofte at foretage en mere grundig proportionalitetsvurdering, ligesom der ofte kun er meget begrænset vejledning til retsanvenderne. Dette sker vel at mærke tilfældet i et system, hvor der ikke er etableret forudgående institutionaliseret kontrol af lovgivningen ved andre regeringsuafhængige organer, som fx et lovråd eller et forfatningsudvalg.

Når lovgivningsmagten således kun inddrager internationale menneskerettigheder i sporadisk omfang, giver det også de administrative myndigheder meget spinkle forudsætninger for at sikre overholdelsen af internationale forpligtelser i den konkrete retsanvendelse over for borgerne. De administrative myndigheder er $\mathrm{i}$ vidt omfang blevet overladt ansvaret, men vejledningen i såvel lovtekst som forarbejder er ofte begrænset.

Dette har ikke kun betydning for den reelle gennemslagskraft af de internationale forpligtelser, det har også konsekvenser for, om det overhovedet fortsat giver mening af docere de velkendte principper; fortolkningsformodnings- og instruktionsreglen, når den retlige relevans af international ret skal beskrives. For kan man meningsfuldt beskrive situationen som at der gælder et krav om at fortolke de nationale regler konventionskonformt, når regeringen i det lovforberedende arbejde ikke giver forvaltningen de nødvendige redskaber til at sikre det? Giver det mening at operere med om en formodning om, at lovgiver ikke vil handle i modstrid med internationale forpligtelser, når lovgivningsmagten ikke er mere optaget af at sikre, at menneskerettighederne overholdes i den konkrete anvendelse af reglerne? Og hvad er instruktionsreglen andet og mere end en ideel fordring, som de administrative myndigheder har meget ringe forudsætninger for at opfylde?

Man kan lidt provokerende hævde, at disse klassiske principper udelukkende tjener til at opretholde en illusion om betydningen af international ret $\mathrm{i}$ dansk ret, en betydning som ikke overbevisende kan genfindes $\mathrm{i}$ praksis.

Det er i den forbindelse vigtigt at nævne, at de administrative myndigheder naturligvis spiller en central rolle i implementeringsprocessen, idet kun de færreste sager vil blive indbragt for domstolene. Hvis domstolene får sager forelagt, må de fagligt og ressourcemæssigt betragtes som værende bedre klædt på til at vurdere eventuelle konventionsspørgsmål end forvaltningen, og de kunne derfor principielt tænkes at 'reparere' på de administrative myndigheders mangelfulde behandling og også efter omstændighederne gøre brug af de klassiske fortolkningsprincipper. Domstolene er imidlertid undergivet et klart formuleret fortolkningsdirektiv om tilbageholdenhed, så selv i de sager, de rent faktisk behandler, er rollen som garant for menneskerettighedernes overholdelse svækket, og domstolene kan aldrig til fulde kompensere for den begrænsede inddragelse af konventionerne ved lovgivningsmagten og ved de administrative myndigheder.

\section{Afrunding og diskussion}

International ret opstiller grænser for staten, heriblandt lovgivningsmagten. Ligesom ved grundlovsnormer skaber det en række politiske og juridiske dilemmaer. Danmark har formelt set opretholdt en dualistisk og dermed defensiv strategi i diskussionerne om international ret i dansk ret, men samtidigt hårdnakket holdt fast $i$, at det ingen reel betydning har haft for de internationale normers gennemslagskraft i praksis. 
Nyere lovgivningspraksis viser imidlertid, at regeringen praktiserer en relativt minimalistisk fortolkningsstil $\mathrm{i}$ sin brug af international ret i lovgivningsprocessen, og at der langt fra er tale om en løbende, omfattende og grundig behandling af fortolkningsspørgsmål og konfliktmuligheder i forhold til Danmarks konventionsmæssige forpligtelser. Domstolenes fortolkning er længe blevet betegnet som forsigtig, men lovgivningsmagtens fortolkning kan på baggrund af de foretagne analyser betegnes som tilsvarende og om muligt endnu mere tilbageholdende. Domstolene og andre retsanvendende myndigheder kan altså ikke nødvendigvis "gå ud fra en formodning om, at lovgivningen er forenelig med konventionskomplekset", hvilket var et af hovedargumenterne for at afstå fra yderligere inkorporering. Og de administrative myndigheder vil ofte have opmærksomheden mere rettet mod nationale end internationale retskilder og kan ikke som sådan forventes at udfylde det implementeringsmæssige tomrum, som lovgivningsmagten efterlader dem i.

Disse forhold rykker også ved overbevisningskraften af det centrale argument om, at anvendelsen af international ret i dansk ret ikke må indebære en forrykkelse af det traditionelle magtforhold mellem lovgivningsmagten og domstolene. Sat på spidsen kan man nærmest betegne situationen som den absolutte ansvarsforflygtigelse, for lovgivningsmagten har pålagt domstolene tilbageholdenhed, men $\varnothing$ nsker heller ikke selv at påtage sig opgaven med at sikre en effektiv implementering.

Efter min opfattelse giver det således ikke længere mening at docere de velkendte grundsætninger om international rets status i dansk ret og fx fortolknings- og formodningsreglen, når en så central aktør som lovgivningsmagten tillægger de internationale normer så relativt begrænset betydning. De kan måske fungere som normative pejlemærker for, hvordan retstilstanden burde være, men de kan ikke meningsfuldt betragtes som udtryk for, hvordan retstilstanden rent faktisk er. Kigger man mere nøgternt på betydningen af international ret i de analyserede situationer, er det formentlig mere retvisende at karakterisere det danske system for ekstremt dualistisk, således at internationale menneskerettigheder kun meget begrænset og modvilligt inddrages i situationer, hvor der er konfliktpotentiale til ønsket national regulering.

I sidste århundrede kunne man beskylde den juridiske teori om forholdet mellem international ret og dansk ret for at være abstrakt og virkelighedsfjern, men dette skyldtes til dels, at der langt op i det 20. århundrede trods alt kun var en begrænset mængde praksis at forholde sig til. Nu synes teorien stadig at være virkelighedsfjern, men af en anden årsag. Litteraturen har ikke hidtil forholdt sig til den centrale rolle, som lovgivningsmagten spiller som forfatningsretlig aktør, når forholdet mellem national ret og international ret skal fastslås. Dette skulle denne artikel gerne have bidraget til at råde bod på. 